\section{Small ideas for big impacts: Multifunctionality in the rural village of Verkykerskop}

\author{
Jako Viviers \\ DOI: http://dx.doi.org/10.18820/2415-0495/trp73.2 \\ Peer reviewed and revised October 2018 \\ ${ }^{*}$ The authors declared no conflict of interest for this title or article
}

\begin{abstract}
Nijkamp affirms the Utopians' claim of an open and flexible future, where development could imply surprising steps towards something better. Castells questions admonishingly whether planning approaches are changeable in a world that has already changed. Following Davidoff's indications of making urban life beautiful, exciting and creative, planners encounter "surprising steps" within the planning approaches of compact cities, new urbanism, new ruralism, smart growth, green urbanism, and so on. In responding to Castells' "multidimensional change in the spatial dimension", the imagination of planners is intercepted, angling them towards a multifunctional planning advent. This article reasons that a combination of the new urbanism, green urbanism and new ruralism may be a beneficial response to multifunctionality, especially as megatrends emphasise the need to abandon the pursuit of a predictable single future or outcome. It questions whether the reciprocal use of these planning approaches may induce multifunctional rural landscapes. The uniqueness of the inherently rural South African landscape also necessitates a rural emphasis in this article, questioning whether the reciprocal use of the three planning approaches in the recently planned rural village of Verkykerskop, acclaimed by the Charter for New Urbanism in 2012, generated multifunctional rural land use.
\end{abstract}

Keywords: Green urbanism, multifunctionality, new ruralism, new urbanism, rural landscapes, urban design

\section{KLEIN IDEES VIR GROOT IMPAK: MULTIFUNKSIONALITEIT IN DIE PLATTELANDSE DORPIE VERKYKERSKOP}

Nijkamp benadruk die utopiese aanspraak dat die toekoms oop en buigsaam is, waar ontwikkeling verrassende treë tot "iets beter" kan impliseer. Castell bevraagteken vermanend of beplanningsbenaderings kan verander in 'n wêreld wat reeds verander het. In Davidoff se siening dat die lewe in die stad gestalte kan vind in 'n pragtige, opwindende en kreatiewe milieu, vind beplanners "verrassende treë" in die konsepte van kompakte stede, nuwe urbanisme, slim-groei, groen urbanisme, en dies meer. In reaksie op Castell se "multidimensionele verandering in die ruimtelike dimensie", word die verbeelding van beplanners aangegryp en ge-oriënteer na 'n multifunksionele beskouing van beplanning. Hierdie artikel voer aan dat die kombinering van die beplanningsbenaderings van nuwe urbanisme, "nuwe landelikheid" en groen urbanisme 'n moontlike antwoord vir multifunksionaliteit kan wees, veral aangesien mega-tendense benadruk dat daar wegbeweeg behoort te word van die soeke na 'n voorspelbare en enkelvoudige uitkoms. Die artikel besin of die wedersydse toepassing van die drie beplanningsbenaderings moontlik multifunksionele landelike landskappe tot gevolg kan hê. Die uniekheid van die inherent landelike Suid-Afrikaanse landskap noodsaak ook 'n landelike fokus in hierdie artikel. Daar word bevraagteken of die wedersydse toepassing van die drie beplanningsbenaderings in die onlangs beplande landelike dorpie van Verkykerskop, wat in 2012 'n toekenning van die Charter for New Urbanism ontvang het, 'n multifunksionele landelike grondgebruik in die hand werk.

Sleutelwoorde: Groen urbanisme, landelike omgewings, multifunksionaliteit, nuwe urbanisme, nuwe landelikheid, stedelike ontwerp

\section{MEHOPOLO E MENNYANE BAKENG SA TSHUSUMETSO E KGOLO: DITSHEBELETSO TSE NGATA MOTSE-LEHAENG WA VERKYERSKOP}

Nijkamp o tiisa tseko ya "the Utopians" ya bokamoso bo bulehileng, bo fetohang habobebe, moo teng ntshetsopele e ka hlahisang ditsela tse isang nthong e betere. Katamelo e entsweng ke Castells, e botsolotsa taba ya hore na mekgwa ya ho tobana le meralo e kgona ho fetoha lefatsheng le seng le fetohile. Ho latela pontsho ya Davidoff ya ho etsa bophelo ba toropo bo be botle, bo thabise le ho ba le mekgwa e metjha; bahlophisi ba kopana le "mehato e makatsang" dipakeng tsa mekgwa ya ditoropo tse nnyane, ketsobotjha ya toropo (NU), ketsobotjha ya mahae (NR), kgolo e ntle "green urbanism" (GU), le tse ding. Ho arabeng taba ya Castells ya "diphethoho tse ngata tekanyong ya sepakapaka" (multidimensional change in the spatial dimension), menahano ya bahlophisi e a thibelwa/sitiswa, e lebiswa lehlakoreng la moralo o nang le mesebetsi e mengata. Atikele ena e fana ka mabaka a hore kopanyo ya NU, GU le NR, e ka kgona hore e be ntho e nang le molemo bakeng sa ditshebeletso tse ngata, haholoholo ha ditlwaelo tsa batho ba bangata di hatella tlhoko ya ho emisa telekiso ya ho ba le bokamoso kapa sephetho se le seng. $E$ botsolotsa hore ebe tshebediso ya mekgwa ena e neletsanang ya moralo e tla etsa bokgabane/botle ba dinaha tsa mahaeng/mapolasing na. Ho kgetheha ha bokgabane/botle ba dinaha tsa Afrika e Borwa, tseo e leng mahae/mapolasi ka thaho, bo hloka hore mahae/mapolasi a hlahelle atikeleng ena, bo botsolotsa tshebediso e neletsanang ya boraro (NU, GU le NR) "trio" ya mekgwa ya ho rala motse-mahae wa Verkykerskop o qetang ho ralwa nakong e seng kae e sa tswa feta. O rotloetswang ke Tjhata ya ketsobotjha ya toropo ka 2012 "the Charter for New Urbanism in 2012", e entseng ditshebetso tse ngata tsa lefatshe mahaeng/mapolasing.

\section{INTRODUCTION: "THE WORLD HAS CHANGED"}

Castells (1992: 73) poses the inevitable warning question to the planning fraternity as to whether its approaches are changeable in a world that has already changed. The resultant effect of the former political dispensation in South Africa heightened spatially distorted settlement patterns, characterised by fragmented urban forms, distinctive of robust racial segregation. The precedence restructuring is relishing on the South African planning agenda as a consequence of the recently promulgated Spatial Planning and Land Use Management Act (No. 16 of 2013), urging the resolve of distorted settlement 
patterns, and requiring scholars and professionals to take their creative successes to the academic discourse and to progressively grapple the less familiar and innovative nuances of planning.

As a planning profession is expected to create a more beautiful, exciting, creative and more just urban life, Davidoff (1965: 331-338) charged planners in 1965 as "having little to say". In prescribing future urban life, the obligation was to ensure a generation of planners to surpass those of the1960s. Nijkamp (1980: 241) later affirmed the utopians' claim that the future is open and flexible, and that every development in the community could imply a surprising step towards something better. Nearly 40 years later, planners encounter ever-increasing approaches "towards something better", oscillating from compact cities, transit-oriented developments, new urbanism (NU), new ruralism (NR), shared cities, to smart growth and, of late, eco-cities; all in response to a prospect where monofunctional and one-dimensional planning are gradually surpassed by multifunctional hybrid alternatives and the optimum utilisation of land. These approaches outpaced the methodologies of the 1960s, where urban planning was branded as homogeneous development, leading to spatially separate residential, working and commercial areas (Jacobs, 1961: 32). In responding to homogeneous development and the "multidimensional change in the spatial dimension" revealed by Castells (1992: 73), the imagination of planners is progressively intercepted, angling them towards a multifunctional planning advent. This collaborative and aggregated approach is comprehensible, especially considering Katz's (1994: ix) alarming caution that the suburban paradigm that has dominated since the 1940s and 1950s will not be able to meaningfully sustain another generation of growth.

Planning approaches, therefore, inevitably need to have a new historical starting point, of which planners may well be a significant part (Castells, 1992: 78). Gunder and Hillier (2009: 195) equally recommend that "for planning to be innovative, practitioners need to engage with challenges and alternative ways of doing and thinking". Pre-shaped and mechanically defined solutions, in a world that has already changed, compel us to revisit and critically evaluate where we are, where we may wish to go, and what we wish to become as communities - in essence, a restored narrative that reflects solutions beyond apparent monofunctional planning. In a new realm, Ahern (2011: 4) senses that planners will have to explore innovative ways of providing for "sustainable ecosystem services in the increasingly limited spaces within compact cities". He continues that multifunctionality is "inherently efficient spatially and economically" and benefits from support by communities and role players; all as a consequence of the multiple functions it endorses. In specifically observing the rural context, Dijst, Elbersen and Willis (2010: 3-6) emphasise that traditional planning policies are no longer suitably addressing the demands stemming from a diverse group of actors, typically found in rural areas. Balmford, Bruner, Cooper et al. (2002: 950) simply maintain that the multifunctional and sustainable use of natural landscapes typically surpasses "gains of their conversion to single-purpose land use types", the latter signalling the alien nature of monofunctional tactics in a rapidly changing world. The weight of the monofunctionality of the $20^{\text {th }}$ century is recurrently bewailed as an "inherent burden that we must leave behind" (Brandt \& Vejre, 2004: 28).

In attaining multifunctional planning, this article reasons that a combination of design approaches may be a response to a world that has changed, especially as megatrends emphasise the need to abandon the pursuit of a predictable single future or outcome (Retief, Bond, Pope et al., 2016: 56). Using theoretical sampling as a component of a qualitative inquiry into the recently designed rural village of Verkykerskop, acclaimed by the Charter for New Urbanism in 2012, raises the question as to whether the reciprocal employment of the design approaches of NU, NR and green urbanism (GU) may well induce multifunctionality. As this research deals with numerous "how" questions, a case study is deemed the appropriate strategy. Verkykerskop is selected as a single, unique and revelatory case study (Yin, 2003: $1,39,42)$, providing "rich and vivid descriptions" (Cohen, Manion \& Morrison, 2018: 376). It presents an exclusive and distinctive (Cohen et al., 2018: 223) design philosophy, realising farming, playing and living through the collective employment of NU, NR and GU.

\section{RISE OF THE MULTIFUNCTIONALITY DISCOURSE}

\subsection{Scientific point of departure}

Notwithstanding the increasing attention that multifunctionality gained over the past decade, planners are progressively experiencing frustration (OECD, 2001: 9) regarding a proper set of broad definitions and clear statements concerning its scientific points of departure. Although the concept is relatively new, it appears that what it presents, is not new (Bohman, Cooper, Mullarkey et al., 1999: 5). It first appeared in the agricultural dialogue. Holmes (2006: 142) perceived agriculture production as intended (food outputs) and unintended (non-food outputs) by-products. This gradually progressed by dredging up old ideas and practices and converting them into new ones, now being embraced by several disciplines. By way of illustration, the European Commission (2012: 3) claims that the multifunctional application of green infrastructure contributes to the achievement of a number of policy aims and fulfils the needs of a variety of stakeholder groups. Several scholars similarly view multifunctional planning as a feasible methodology 
to embark on the contests of a changed world (Kopeva, Peneva \& Madjarova, 2010; Brand \& Vejre, 2004; Ahern, 2011; Vreeker, 2004).

In meeting the evolving complex and multiple societal demands on rural land use, interests are increasingly mounting in comprehending multifunctionality. Brandt and Vejre (2004: 7) suggest that multifunctionality should essentially seek a transfer from "functional segregation towards functional integration". Batty, Besussi, Maat and Harts (2011: 333) highlight the intricacy of its attainment, stating that the "concept of multifunctionality and mixed use is more convoluted spatially than its discussion implies". They recognise it as a theme running through many substantive discussions of the contemporary planning scene. Supportive of this interpretation, Vreeker (2004: 1-18) comprehends multifunctionality as a form of development whereby different land uses are concentrated in a specific area, resulting in synergy among the combined land-use functions. In framing a structured multifunctional point of departure, a threefold approach is assumed: spatially combining separate land parcels that differ in function; applying different functions to the same land parcel, but at different times, and applying different functions to the same land parcel, but at the same time (Brand \& Vejre, 2004: 3-6). Considering its scientific points of departure, Kopeva et al. (2010: 10) elaborate on the increased economic results in peri-urban and rural areas through multifunctionality, suggesting that its combination with economic and ecological principles may well accomplish sustainable development. Holmes (2006: 145) seeks to provide the basic purpose underlying the human use of rural space, narrowing it down to production, consumption and protection, deeming it to be the radical re-ordering principles at the core of multifunctional rural transition. The concept, as perceived by Vreeker (2004: 14), turned out to be an "interesting one", deeming it a spatial planning principle dealing with, inter alia, land scarcity.

\subsection{Multifunctionality and society}

Schama's (1995: 35) leitmotif is simply that "landscapes are culture before they are nature". This is in stark contrast with times when planning was known to be homogeneous and led to spatially disconnect residential, working and commercial areas (Jacobs, 1961: 32). In response to homogeneous approaches, multifunctionality is presented as accomplishing interactive environments and generating social cohesion and economic benefits in the rural community (RSA, 2015: 13). Wilson (2010: 364) presents its broader application to include, among others, the "production" of social functions and social capital evolving in networks of relationships among people residing and labouring in a community, thereby enabling its effective functioning.

Multifunctionality involves "the need to appreciate the significance of space and locality not just as residual variables but as causal social factors in moulding development" (Marsden, Murdoch, Lowe et al., 1993: 20). It appears that multifunctionality requires an equilibrium, not only between environmental and economic attributes, but also between social capital. Hansen and Pauleit (2014: 527) request that multifunctionality should not be assumed in a meagre, quantifiable sense of "the more functions the better", but rather as a normative approach, suggesting a broader planning event whereby settlements are "interrelated social-ecological systems". The significance of multifunctionality is, therefore, embedded in the premise that the landscape already provides social resources, multiple material and immaterial goods to meet societal demands and processing of the landscape on multiple levels. The amalgamation of functions should, among others, offer improved health and well-being benefits for the public, and secure unharmed ecological systems (Lafortezza, Davies, Sanesi \& Konijnendijk, 2013:
102). In utilising the multiple rural goods offered by the landscape, it is possibly in the modest advice from Grandpa to Little Tree that the answer is rooted in taking "only what ye need" (Carter, 1998: 9).

De Groot (2005: 175) shares

Marsden et al.'s (1993: 20) assumptions by arguing for a systematic analysis of the ecological, sociocultural and economic values of the landscape, giving rise to multifunctionality. In attaining these landscapes, he deems the involvement of local people as significant, and their role should be effectively communicated to both planners and authorities. Researchers stoutly advocate collaborative planning among economists, ecologists, social scientists, planners and the community in understanding the compromises involved in land-use change decisions in the rural milieu. In the simplest of premises, Quinn (1999: 47) avers that civilisation must not be abandoned under any circumstances. He reminds us that the elements of our culture ascend from the very structure of our minds: "if you don't have them, there must be something wrong with you". Nelson (2009: 13) sagely admits that, as the physical landscape is examined, so the social landscape must similarly be examined.

\subsection{Multifunctional rural landscapes}

South Africa's distinctive and intrinsic rural landscape necessitates a context-driven reflection on multifunctionality. Notwithstanding the known economic value of the multifunctional use of the natural rural environment, its large-scale obliteration and degradation is looming (Wessels, Prince, Frost \& Van Zyl, 2004: 47). The increasing pressure on the use of rural land, in the absence of continuously improving multifunctional attentions, will result in conflicts and loss of environmental quality (Djist et al., 2010: 4). These pressures relate to demographic and lifestyle changes, increased mobility, the 
growing need for housing in nature, landscape and recreational space conversion, and a demand on rural space for water. Holmes (2006: 141) observes the complexities of rural change in an affluent Western society as multifunctional, where the values of consumption and protection entwine. He questions the former dominance of sheer production in favour of "greater complexity and heterogeneity in rural occupance". In its 2007-2013 Rural Development Programme, the European Commission (2004: 8-9) conversely identified three axes of rural development, signalling the "attractiveness of rural areas, economic diversification and quality of life" as a significant axis. This specific axis should be supplemented by policy measures concerning infrastructure improvement, preservation of cultural heritage, tourism, and micro-enterprise development - all demonstrating a multifunctional disposition towards the planning of rural landscapes.

In countering unceasing agricultural abandonment, Pallarès-Blanch, Prados and Tulla (2014: 2) as well as Bielsa, Pons and Bunce (2005: 85-102) envisage "naturbanization" (an approach, perhaps, to some extent, related to NR), whereby residential dwellers are enticed towards protected natural and rural areas, changing the sociodemographic and economic structure, the form of settlements and the agricultural landscapes. This is, perhaps, akin to Holmes' (2006: 145) contemplating radical re-ordering principles of rural transition. Settlements of this nature incite multifunctionality and enhance a broader economic base for rural land use (Johnson \& Rasker, 1995: 405-416). Audirac, Shermyen and Smith (1990: 473) present the causes for changing residential preferences by opting for "suburban or ex-urban residential environments" as "...the ideal of owning a single family home, the need for an adequate environment for raising a family, a strong desire for privacy and the appeal of a rural ambience". Danbom (1995: 45) raises rural occupancy to an ethical dialogue, signifying that relationships amid friends and neighbours in the farming community should take place in the context of a "moral, rather than a market, economy". We should conceivably avoid portraying rural occupancy as a solely economic and demographic phenomenon.

Kopevav et al. (2010: 3) echo the current debate in theory and practice relating to the opposing approaches of multifunctional agriculture and multifunctional land use. They motivate that both strategies should be interlinked in an outline where land use, biodiversity, and economic, social and environmental dimensions of sustainability are congruently attempted. In deviating from the stance that multifunctionality is simply a survival strategy for farmers and emphasising the interwoven nature thereof, Marsden and Sonnino (2008: 423) distinguish activities, under the emerging paradigm, as conducive thereto: adding income and opportunities; establishing new agricultural sectors that address societal needs, and instituting the redefinition and reconfiguration of rural resources in, and beyond farming. Vereijken's (2002: 177) research elucidates the ongoing transition from the monofunctional use of agricultural land to multifunctional land use. He endorses physical and economic restructuring. In principle, "dualistic planning" is predicted, by permitting areas for openness, quietness and silence, where the emphasis is on nature, recreation, cultivated farms and grazing and by entitling areas for "main road" functions, permitting living, soft (retailers and services) and hard enterprises (production, trade and transport). In the European theatre, it appears that multifunctionality is discussed against the background of changing conditions relating to diverse agricultural production. Consequently, agriculture is viewed, to a lesser extent, within the context of sheer production (food outputs), but rather within the context of its tributary resources such as protection, leisure, recovering space, and the cultural landscape (non-food outputs).

The principles of multifunctionality will initially be coded and categorised, and themes will ultimately be developed (Cohen et al., 2018: 673) deemed inherent in the multifunctional discourse. The selected themes of multifunctionality will be included in a theoretical matrix (see Table 1) that will be used in analysing theoretical data. This analysis will seek the interface between the themes of multifunctionality and the aggregated principles of the planning approaches of NU, NR and GU. In further preparing this analysis, the structure of this article explores the selected planning approaches as plausible building blocks in response to multifunctionality.

\section{THE RATIONALE FOR AGGREGATING PLANNING APPROACHES}

"Urban design is a fundamental, essential ingredient of our intellectual tradition, yet it cannot provide the only material basis for the reconstruction of our field in the face of new historical challenges" (Castells, 1992: 77). This assertion mirrors Castells' covenant with earlier academics, sensing that a monofunctional approach is deemed obsolete in meeting the appeals of a changed world. Although it appears that the records of scholars, incoherently contemplating the planning approaches of NU, NR and $\mathrm{GU}$, are saturated, this contrasts with a minor group of academics seeking the collective interface between these planning approaches in their quest to attain multifunctionality. They increasingly portray the future process of planning as linking different projects with different functions in prompting spatial synergy (Priemus \& Hall, 2004: 348). In laying down the fundamentals of planning, Hedman and Jaszewski (1984: 1) state that architecture and planning are inseparable and failure to acknowledge their interface is 
"to invite confusion, if not chaos". Implying a potential interface, Stratton (2009: 7) positively observes that the future of NR is still optimistic and that the movement is relatively new and exploits the triumphs of NU.

A desired interface is sensed by the European Commission (2012: 4 ), reporting that the nature of green infrastructure, due to its multifunctionality, should not be linked to a single science, especially as its key attraction is to perform "several functions and provide several benefits in the same spatial area”. Kraus (2006: 28), in turn, distinguishes NR as a framework connecting sustainable agriculture and NU, by suggesting an equivalent with the NU vision of compact, mixed use urbanised areas, the elimination of low-density, auto-dependent sprawl and distinct edges between towns and their surrounding rural and agricultural areas. Highlighted by 'pro-ruralists', the rural landscape may be presented as green food belt perimeters, buffers between city and rural lifestyles, countryside residences, small agricultural parks in the urban-rural interface or bigger preserves further afield, including larger farms and rural settlements. It is generally presumed that the interfacing of planning approaches in the same "spatial unit", aside from their status as "spatially well-defined or diffused", may be conducive to the multifunctional landscape (Moffat, 2006: 74; Nelson, 2009: 8; Versaci, 2008: 10; Brandt \& Vejre, 2004: 24). Lehmann (2010: 3) supports the significance of a consolidated planning approach by connecting the definitions of NU and GU, signifying principles for GU. Ultimately and convincingly, he remarks that the "eco-city theory" is the future of all settlements. By the same token, Arendt (1994: 42) views the direct link between NU, environmental benefits and the conservation of sensitive environmental areas as the promotion of compact development patterns, combined with infill strategies.

Despite scholarly suggestions of a promising correlation between planning approaches in a multifunctional means, Newman and Saginor (2016: 2) lament the problem of translating NU principles in the NR philosophy. They caution that rural communities often view the integration of NU concepts in low-density environments as demanding. Jepson and Edwards' (2010: 434-435) research depicts related problems, verifying that planners identify NU, smart growth and the ecological city as complex approaches for which to prepare development strategies. Their findings essentially advocate the planning profession's accountability in formulating a cross or hybrid methodology. The latter verdict prompted this research, in seeking the interface resultant from combining three seemingly intertwined planning approaches. Trudeau (2013: 8) encourages this fusion, as he, like Jepson and Edwards, recommends a "hybrid urbanism" characterised by low-density projects and selecting the qualities of NU concurrently with other planning features, thereby questioning conventional developments. Assuming the planner's position of influence "towards something better" (Davidoff, 1965: 331-338), the limitations of separately using NU, NR and GU are emphasised by offering a clearer sense into its collective defining and correlation. This institutes a developing hybrid approach to planning. Drawn from the research of Ross and Bigon (2018: 23), a "more nuanced" understanding of the grid layout in Senegal indicated hybridisation, further suggesting not only the practical functioning and enhancing of daily urban life, but also replicating a more "inclusive, transnational and cosmopolitan, cum postmodern approach".

\subsection{New urbanism}

Muschamp (1996: 761) labelled new urbanism (NU) as "the most important phenomenon to emerge in American architecture in the postCold War era". He describes the Congress for the New Urbanism's (CNU) commencement with an unpretentious approach, modelling new suburban developments on a compact scale of small towns; increasing residential development density; placing urban amenities within walking distance of houses, and positioning plans toward pedestrians and public transportation. $\mathrm{NU}$ and its continuously updated collaborative "Lexicon of NU" (Plater-Zyberk, 2014: 13) are schools of thought among postsuburban planners, as it introduces a substitute to sprawl through higher densities, diversification, calmed roads, mixed use, and walkability. It has simultaneously cultivated a substantial network of agents in the architectural, engineering, environmental, societal, and planning fields. NU has advanced increasingly in theory and technology. Duany, Pater-Zyberk and Speck (2010: xiii) witness it as, inter alia, introducing the "rural-to-urban transect as an organising structure for conservation and development". The transect displays equivalence with Churchman's (1999: 389-411) arguments in favour of the compact city planning approach, restricting development and higher densities in certain areas, thereby releasing pristine agricultural land from the risks of sheer urbanisation. As a planning approach, NU offers wide-ranging attributes from its development principles to laying foundations for social goals and may well be viewed as an already prevailing multifunctional approach to planning. In addition, it values community, civility, a sense of place, beauty, equity and sustainability, not necessarily reflected upon in familiar and conventional planning approaches (Mayo \& Ellis, 2009: 239).

As with all creations, destruction followed soon and NU has since been laced with criticism from certain academic corners and is becoming different things to different people. Moudon (2000: 42) offers opposing opinions that NU should study its own work, value it critically, and find a baseline from which its progress to date ought to be evaluated. Both its positive and negative responses require explanation, in order to guide planners who are attempting its principles into the next generation 
of development. Ellis (2002: 283) deliberates the vast criticism NU encountered, advising that the standards of academic science claim the need for more evidence, and it should be "exposed by a rigorous, side-by-side comparison of proffered alternatives". Although new urbanists are justified in adhering to their principles, continuing to build, and paying close attention to results on the ground, additional research is nonetheless awaited; research that provides definitive resolutions to the disputed inquiries. Conversely, and as usual, critiques are often preoccupied with lofty generalisations with limited awareness of the routine realities of land development, finance and local politics. They are "letting a rare opportunity to push for a more sane urban development pattern slip through their fingers" (Talen, 2000: 318-337).

In seeking the affiliation between planning principles and social goals, Talen (2002: 184) also underscores the CNU's social goals, indicating that $\mathrm{NU}$ is primarily concerned with common good, followed by social equity and community. Day (2009: 92) acknowledges the value of NU for planners. A single vision should pave the way for an encompassing multiple vision, varied activities, lifestyles and identities. Planners are also requested not to emphasise the economic and environmental consequences of the urban form only, by navigating from social consequences and goals (Duany \& Plater-Zyberk, 1992: 20). NU is, therefore, "new", as it proposes an infrequent approach to planning suburbs, redeveloping cities, and strongly emphasising its inhabitants' well-being. Research concluded in local contexts (AHI, DCOG \& GIZ, 2016: 23) support Duany and Platter-Zyberks' premise that multi-level collaboration and fundamental change may only be attained through extensive dialogue and purposeful engagement with all stakeholders of a settlement.

For the purposes of this article, emphasis is placed on the rural extremity of the NU's "rural-to-urban transect", and correlation is pursued

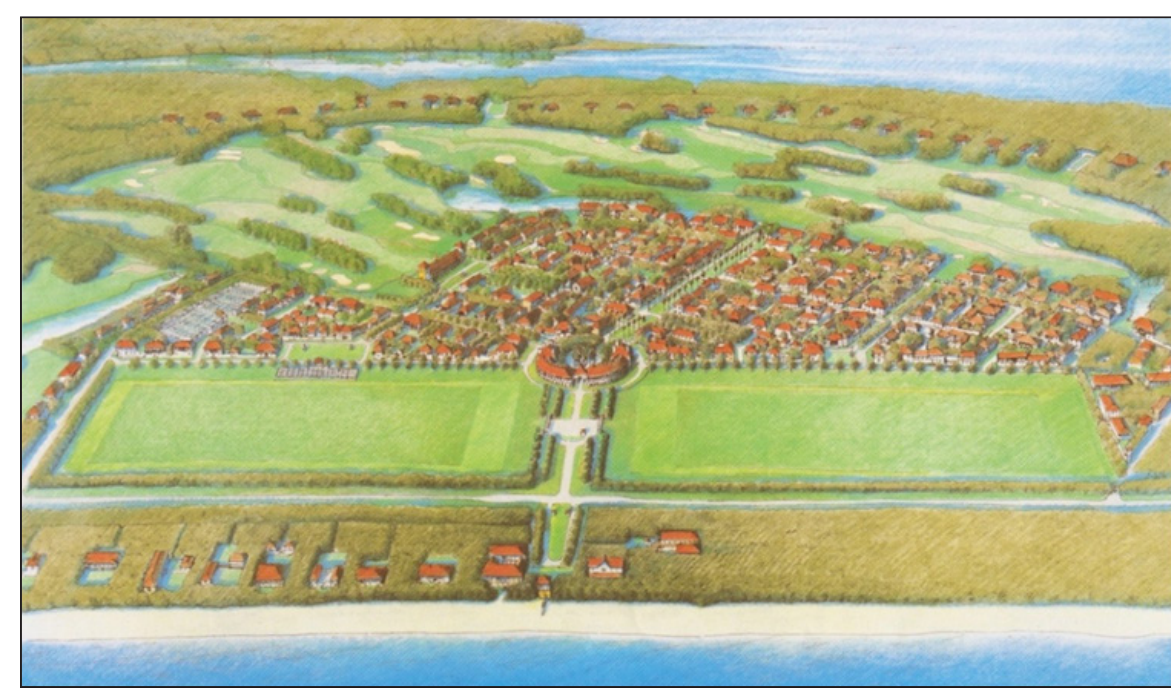

Figure 1: Windsor Village

Source: Katz, 1994: 62

with the findings of Trudeau (2013: 24) that various approaches in $\mathrm{NU}$ are indeed related to different contexts. Bohl (2000: 765) asserts the rural significance of NU, by endorsing rural hamlets and villages, small towns in districts that afford compact alternatives applicable to different rural settings. Limited research on NU in its rural context requires a better understanding of the different scales at which settlements are shaped, as well as the relationships that exist between elements at the different scales (IURD \& SAGE, 2006).

This article finds itself taking small steps in resolving certain limits of NU in rural context.

In putting forward a reasonable urban framework for the essentially rural case study, the Windsor model (Figure 1), a decidedly successful $\mathrm{NU}$ village in the United States of America (Katz, 1994: 62-77), was viewed as a likely planning equivalent. The latter, mostly as a consequence of pertinent spatial similarities between the two villages. The urban form and rural locality of Windsor were deemed more relevant, not necessarily its cultural or architectural context.

\subsection{New ruralism}

"Whatever events in progress shall go to disgust men with cities, and infuse into them the passion for country life, and country pleasures, will render a service to the whole face of this continent..." (Ralph Waldo Emerson, 1944) (Machor, 1987: 157).

Emerson's foretelling statement is reminiscent of Holmes' (2006: 144) research, as he observes that the rural landscape is increasingly being "consumed" by market-driven interests, "attracted by a residential, tourism and recreational lifestyle or investment opportunities and by farm households increasingly dependent on non-farm income". Leisure activities and farm-based recreation, of late, are backing the fulfilment of Emerson's prediction and are often mentioned as possibilities for farm diversification. Unlike land use for exclusive food production and decreasing landscape diversity, multifunctional use nurtures an altered landscape that may still be dominated by wide expanses of agriculture-related activities, complemented by progressively developing non-productive activities and functions, often from private and small initiatives (Elgåker, 2012: 592). Although Nelson (2009: 13, 96) agrees that the forces of the NR are already afoot, they are only rudimentarily theorised. He perceives NR as a necessary step in "sharpening the resolution with which social scientists can describe the effect of place on people". Understanding NR is progressively increasing, as academics and 
practitioners, especially in the European theatre, are intent on framing its definition, approaches and priorities. In essence, NR is entrenched in past models, comparable with the agricultural context of the 'Garden City' and the self-sufficiency components of agri- and eco-villages.

NR may accordingly be viewed as an approach built on the past two decades' cumbersome reform in food, agriculture and land-use planning, whereby sustainable agriculture made farmers' markets a basic amenity of a town centre (Kraus, 2006: 28). During this time, new alternative approaches showed the possibilities of creating healthier, more liveable rural centres. Kraus (2006: 27) views NR as a "corollary of $\mathrm{NU}$, with a related framework of principles, policies and practices". In attempting to provide a more refined meaning of NR, Newman and Saginor (2016: 2) recommend that it should encompass "clustered, small- to medium-scaled suburban style developments, occurring in rural areas, under urban influence, characterised by large ratios of viable preserved farmland, that contribute to local and regional food systems and help contain/ sustain metropolitan regions". In attaining permanent preserves, as a primary goal of $\mathrm{NR}$, their research also ascertains multiple economic opportunities, optimal preservation of farmland and green space, and ensuring stable and adaptable working farms. Kvorning (2016: 26) recommends a similar holistic view of NR. He highlights the current debates' emphasis on a specific lifestyle where people want to "rediscover and re-utilise" the delicacies of life in the rural landscape. Said lifestyles advocate a new form of sustainable life in the countryside, incorporating social, environmental, and economic sustainability.

It appears that the application of NR is more appropriate on a smaller scale of sustainable agriculture, overlapping with areas for wildlife and habitat management. It provides the opportunity for adding value to agricultural areas, in order to permit clustered residential development (Moffat, 2006: 74). Versaci (2008: 10) reasons that NR ought to be regarded as the inverse of NU. He suggests a strategy to develop new communities in the rural landscape, offering a way to preserve its landscape and architectural heritage (typically illustrated in the case study of Verkykerskop in Figure 2). NR is described as a better way to promote rural areas, seeking to preserve the "ambiance of a place" by understanding traditions, patterns and customs in planning new communities. The Lexicon of NU (Plater-Zyberk, 2014: 13) positively endorses this assumption, emphasising that the planning and re-planning of settlements should take cognisance of "historical patterns, precedents and boundaries". At its core, NR considers environmental stewardship in a context of conserving agricultural land (preserves) for vernacular architectural traditions, wildlife habitat, natural settings, and recreation (Versaci, 2008:
10). Imminent development markets, where prospective residents experience country life and its pristine landscapes as desirable are, among others, an additional consequence of NR.

In deliberating a clearer framework for NR, scholars at the University of California (IURD \& SAGE, 2006) emphasised the contributions by Dean Fraker that NR is a combination of many different parts, with pertinent linkages between the built environment, health and urban-rural interface issues. They concluded that, above all, "NR is not just the absence of urbanism". Prominence is equally placed on the local agenda by Louw (2012: 1-143) who regards NU and NR as potential tools for sustainable development in South Africa's rural setting. Most recently, the South African rural landscape was competently divided into cities, smaller towns, rural villages and countryside; thus, final destinations announcing the vast wilderness in between. Farmsteads, built in the regional vernacular style, were dispersed throughout a mainly open landscape, while small rural towns served as centres for the surrounding agricultural community. Rather than bulldozing this unique countryside into oblivion, the South African rural landscape echoes Versaci's (2008: 12) awareness that the preservation developments of NR may "draw the best of the past into the present". Communities seeking to preserve their natural resources and cultural heritage find comfort in Stratton's (2009: 7) assurance that they are not alone, predicting that NR is
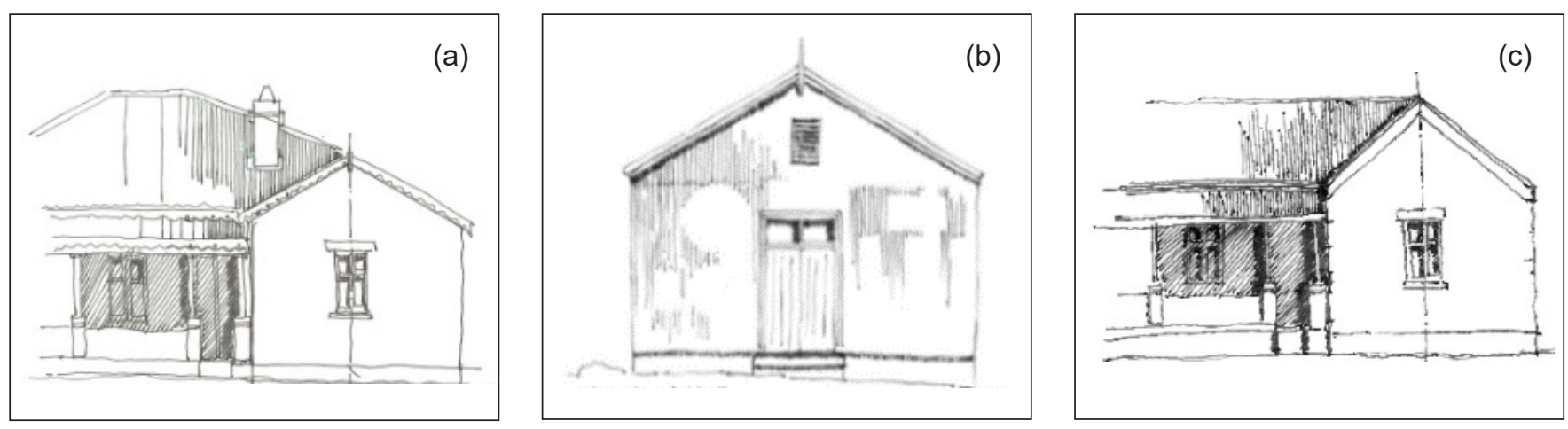

Figure 2: Facade studies of vernacular architecture in the Verkykerskop region

Source: $\quad$ GWA Studio, 2014: 30 
the "vaccine" against sprawl and a way to "ward off the encroachment of those who see the land as an accessory and not a commodity".

\subsection{Green urbanism}

In a world that has changed, Castells (1992: 77) alerts planners that environmental planning will be "the most rapidly increasing planning frontier in the United States in the next decade". Freilich \& Popowitz (2010: 1) also admit that the first decade of the $21^{\text {st }}$ century spawned extraordinary levels of environmental awareness and action globally. Howard (1902: 1-195) suggested that $\mathrm{GU}$ as a political and social agenda "recently" surfaced. McHarg (1971: 5) states that society was already urged in the 1960s to "give expression to the potential harmony of man-nature", which he oscillated in the 1980s by stating that ecological planning should meet the requirements of both user and nature (McHarg, 1981: 109). The turn of the century saw a global diaspora of sustainability principles into neighbourhood planning (Sharifi, 2016: 1). GU, as a planning approach, is contemporarily viewed as metamorphic, presented in various forms and tributaries. It developed globally as a way of comprehending how green resources and ecological systems function as part of the infrastructural fabric that supports and sustains society and builds resilience (Harrison, Bobbins, Culwick et al., 2014: 67). Lafortezza et al. (2013: 102) propose that the city and its adjacent "wildland interface" are the most useful zones for the implementation of green infrastructure, environment and urban planning, largely accepted as "GU". It focuses on correcting the relationship between urban and nature and has developed as a conceptual and theoretical basis for a new planning archetype.

Despite noticeable advances to date, Beatley and Newman (2009: 216) agree that we are only attempting sustainability, how to use less and live better, how to rejuvenate the "ecology of the city and its bio-region", and that "sense of place, means something in a globalised economy". By contrast, Palmer and Simon (2016: 16) dispute that the world is unable to "merely afford urban sustainability utopianism". Considering their opposing assertion, equated with the scholarly emphasis on GU, this article contemplates whether the measly application of a single planning approach (GU) will construe the "rapidly increasing planning frontier". Or, will a progressive understanding of the reciprocal application of several planning approaches provide solutions in fostering multifunctional landscapes? Various scholars examined the integrated disposition of GU, especially Freilich and Popowitz (2010: 4) who expect that smart growth, NU and GU (and renewable energy) should be combined and employed interchangeably, integrably and in a comprehensive fashion. They continue that this approach is a far broader and useful treatment of various planning approaches, thereby suggesting a multifunctional planning approach. The current regard for green infrastructure is intrinsically reliant on its multifunctionality and its capability to address several challenges concurrently by offering sustainable solutions (European Commission, 2012: 25). In reviewing megatrends that are rapidly changing in a world that has changed, Retief et al. (2016: 58) underscore their view that the "most promising approach is a shift in practitioners' thinking towards the possibility of multiple possible futures of any one proposal because thinking of a predictable single future or outcome is unlikely to succeed". Tîrlă, Manea, Vijulie et al. (2014: 462) indicate to planners that the persistent dilemmas of the $21^{\text {st }}$ century are focused on rapid exhaustion of conventional energy resources, abrupt urbanisation, pollution at various levels, and global warming; all having an impact on the quality of life and consequently necessitating reconsideration when planning settlements. They claim that this re-examination ought to consider a multidisciplinary approach to compact settlements, green transport, ecosystem services, urban greening by means of community gardens, green roofs and urban agriculture, renewable energy projects, a sense of place, and lifestyle.
Lehmann (2010: 3 ) is resolute that our "cities can and must become the most environmentally friendly model for inhabiting our earth". He continues that GU is not viewed as a phenomenon confined to élite academia, but that it ought to be applied as standard approach in planning new settlements. In broadening its applicability, Artmann, Bastian \& Grunewald (2017: 14, 19) further emphasise the phenomenon's significance on a regional scale, applied beyond settlement planning. In an era of rapid urbanisation, of which Africa is reported to take an unenviable lead of $3,5 \%$ per annum (Adesina, Gurria \& Helen, 2016), higher levels of environmental awareness are terms that should elicit decisive action and not be viewed as fad by planners and authorities. Rapid urbanisation in the local context wants a pertinent encounter with $\mathrm{GU}$, moving from the "far-sighted planning of urban areas towards more sustainable and liveable places" (Retief et al., 2016: 54). In this manner, multifunctionality is advocated as a normative concept, taking a broad perspective on urban and rural areas as interrelated socio-ecological systems. Hansen and Pauleit (2014: 516-529) promote green infrastructure and ecosystem services, confirming that these seek to combine "ecological, social and economic/abiotic, biotic and cultural functions of green spaces". It could develop as an innovative planning approach, capturing the complexity and dynamic of socio-ecological systems in the built environment, and supporting the concepts of sustainable development, environmental justice, social cohesion, and resilience. In addition to its apparent ecological benefits, green infrastructure has the ability to evolve as a local tourist asset, enhancing the communities' economic benefits and selfsustainability (Tîrlă et al., 2014: 476).

Despite the various social, fiscal and environmental tributaries combined with the urban cum rural application of GU, a transition from "spot sustainability" to cohesive strategies, producing a greater sum than its parts, ought to be pursued (Freilich \& Popowitz, 2010: 4). The 
question remains whether GU will attain sustainability, either in its singular or reciprocal application with other planning approaches. Gunder and Hillier (2009: 141) profess that it will not, as they recognise that "no one knows or can succinctly or comprehensively and universally define what the sustainable city, social justice or the common good, for that matter, actually is".

\section{VERKYKERSKOP: MULTIFUNCTIONAL URBAN PLANNING SUBSTANCE}

\subsection{Methodology}

This article uses selected procedures (Cohen et al., 2018: 714) embedded in grounded theory, i.e. theoretical sampling (Suri, 2011: 7) and coding to ultimately generate a theory pertaining to the attainment of multifunctionality in the rural context. By using a process of "open coding" (Cohen et al., 2018: 670), the progression of the principles of multifunctionality into categories and themes considered intrinsic to the multifunctional narrative was described in concluding section 2 . The identified themes are listed in the ensuing emergent theoretical matrix (see Table 1). This article also deliberates whether the reciprocal use of the three distinctive planning approaches of NU, NR and GU may well induce multifunctionality. Neither these planning approaches nor their related principles are exhaustive and there is room to change or expand the scope of this research in the future. ${ }^{1}$ All planning principles were, therefore, not selected, but merely a purposeful selection for the scope of this article as portrayed in the emergent theoretical matrix.

'Direct content analysis' is used to assess the research content, as the coding structure was derived from pre-existing theory (Newby, 2010: 485). This process illustrates potential linkages, correlations and the interface with the themes of multifunctionality, with the purposefully selected principles of the planning approaches.

Brandt and Vejre's (2004: 3-32) interpretation that a multifunctional

This article, at its core, aims to illustrate the interface between a trio of planning approaches and multifunctionality, emphasising the planning of rural landscapes. Its purpose is not to provide comprehensive and detailed planning guidelines.

Table 1: $\quad$ Multifunctionality interface with planning principles of NU, NR and GU

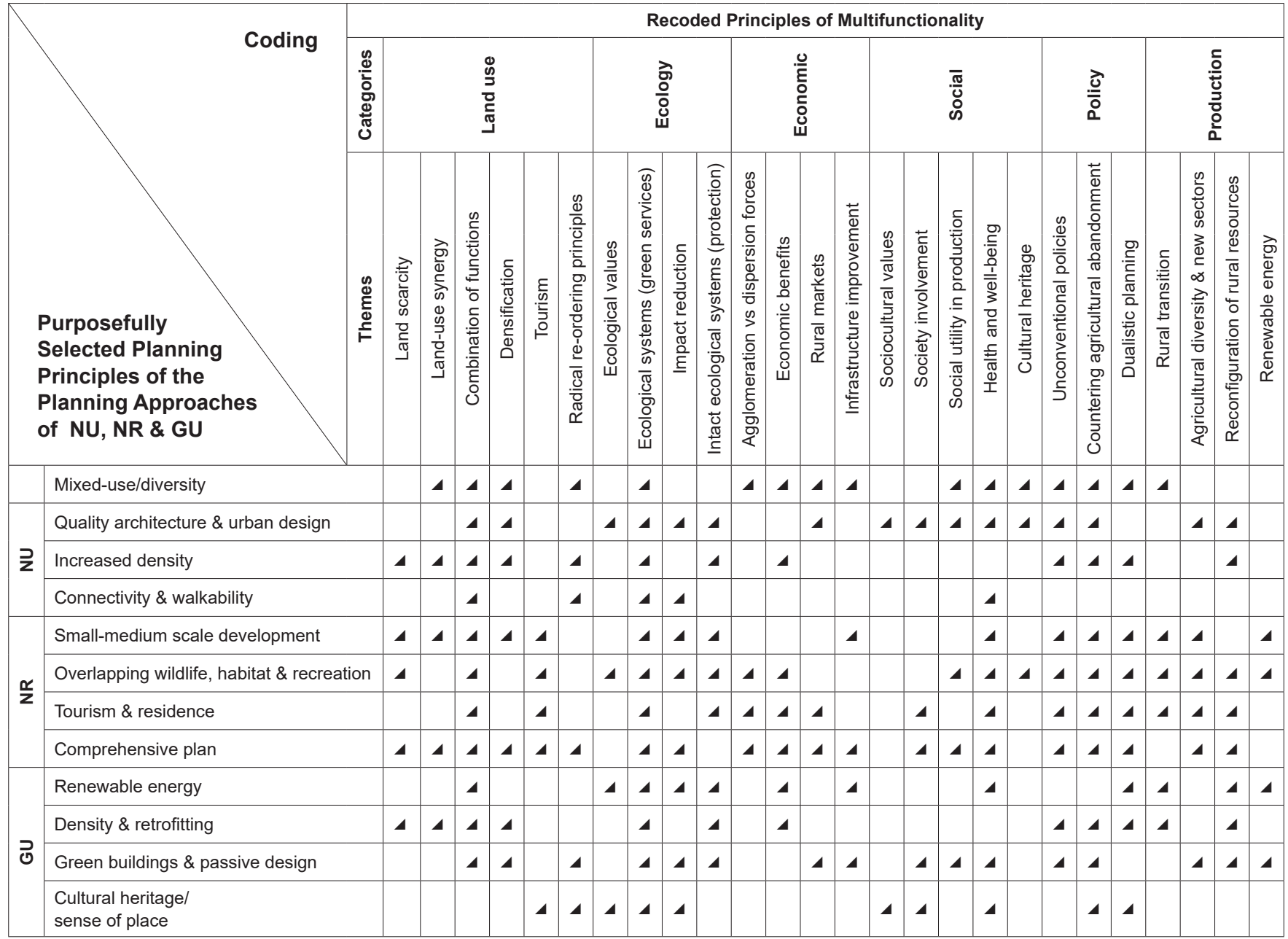

Source: Ahern, 2011; Balmford et al., 2002; Brandt \& Vejre, 2004; Bielsa et al., 2005; De Groot, 2005; Dijst et al., 2010; European Commission, 2004; OECD, 2001; Hansen \& Pauleit, 2014; Hikichi, 2003; Holmes, 2006; Kraus, 2006; Lafortezza et al., 2013; Lehmann, 2010; Marsden \& Sonnino, 2008; Pallarès-Blanch et al., 2014; Vreeker, 2004; Rodenburg \& Nijkamp, 2004; Talen, 2013; Vereijken, 2002; Wiggering, Dalchow, Glemnitz, Helming, Müller, Schultz, Stachow \& Zander, 2006. 

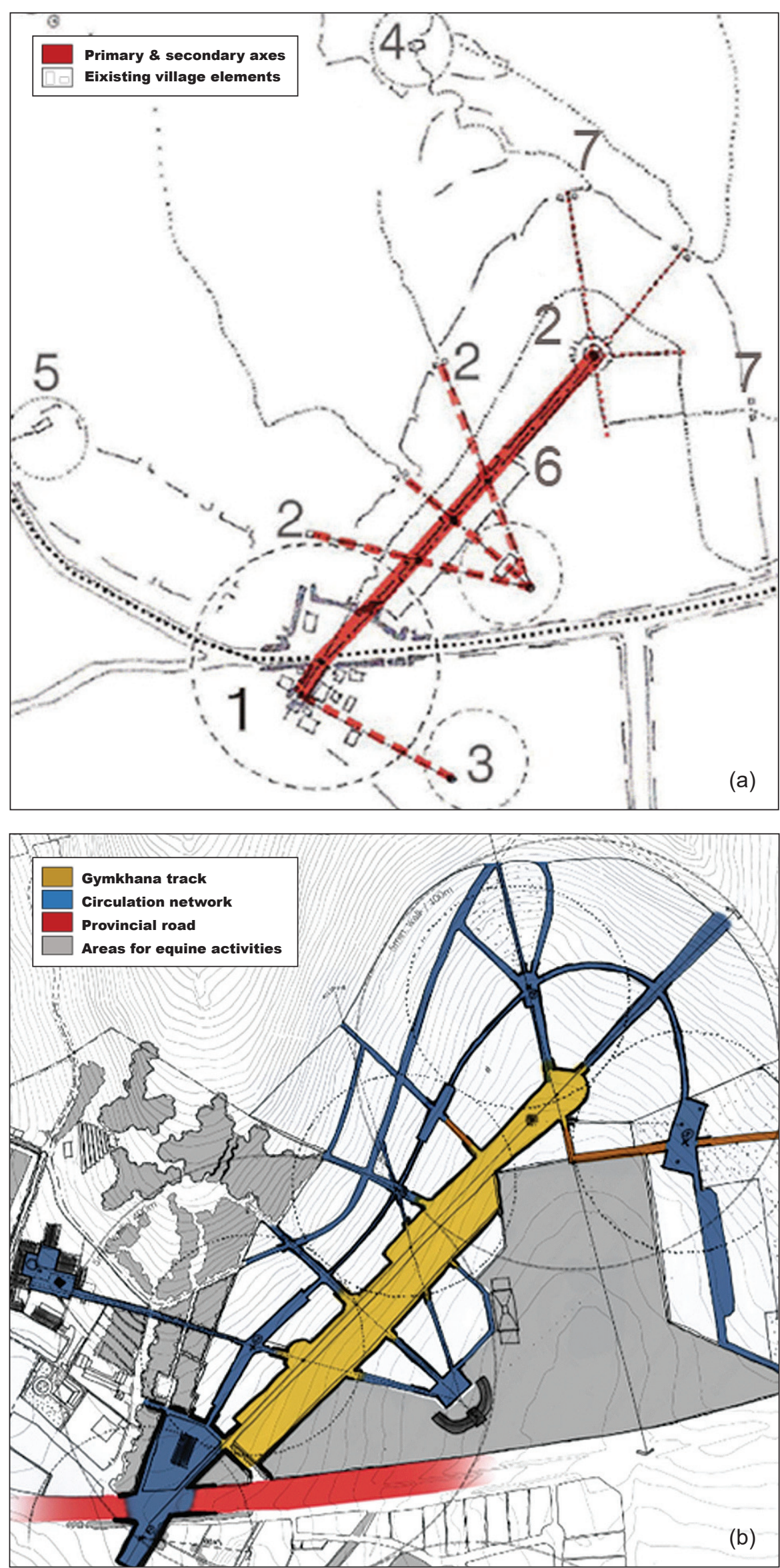

Figure 3: Verkykerskop urban framework: (a) prominent places; (b) regulating axis and pedestrian movement

Source: $\quad$ GWA Studio, 2014: 7, 8 landscape simultaneously comprises several functions is, therefore, accepted. A comparative, correlating (Fram, 2013: 20) and aggregating (Parrachina et al., 2009: 79) content analysis is included in an emergent theoretical matrix, from which conclusions are drawn (Cohen et al., 2018: 675). It is predictable that no single article will conclusively contribute to the current academic, discourse multifunctionality. Table 1 should, therefore, simply be weighed as an emergent analysis. The matrix is not intended to be extensive and does not reflect on the complete assessment that was endeavoured as part of the contributing research. It is acknowledged as a mere illustration of the conduciveness that seems to exist as an outcome of the reciprocal application of the considered planning approaches, as promising tactics to attain multifunctionality.

\subsection{Responses from Verkykerskop}

Selecting the single case of Verkykerskop was prompted by three distinctive hallmarks, as it provides "rich and vivid descriptions", highlights the fusion of three idiosyncratic planning approaches, and is a consequence of the researcher's "integral involvement" with the case (Cohen et al., 2018: 376). Although the purpose of this section is not to comprehensively deliberate all the nominated interfaces, a brief discussion will validate certain applications of the planning approaches followed in Verkykerskop, in responding to multifunctionality. It is accepted that the emergent theoretical matrix has to be improved and developed into a detailed assessment matrix, prior to expansively deliberating all the nominated interfaces. A synthesis of the design philosophy and planning features used during the re-planning of Verkykerskop and its correlation with the interfaced themes of multifunctionality and the principles of the contemplated planning approaches are, therefore, merely noted in the theoretical matrix as a developing assessment of the case 

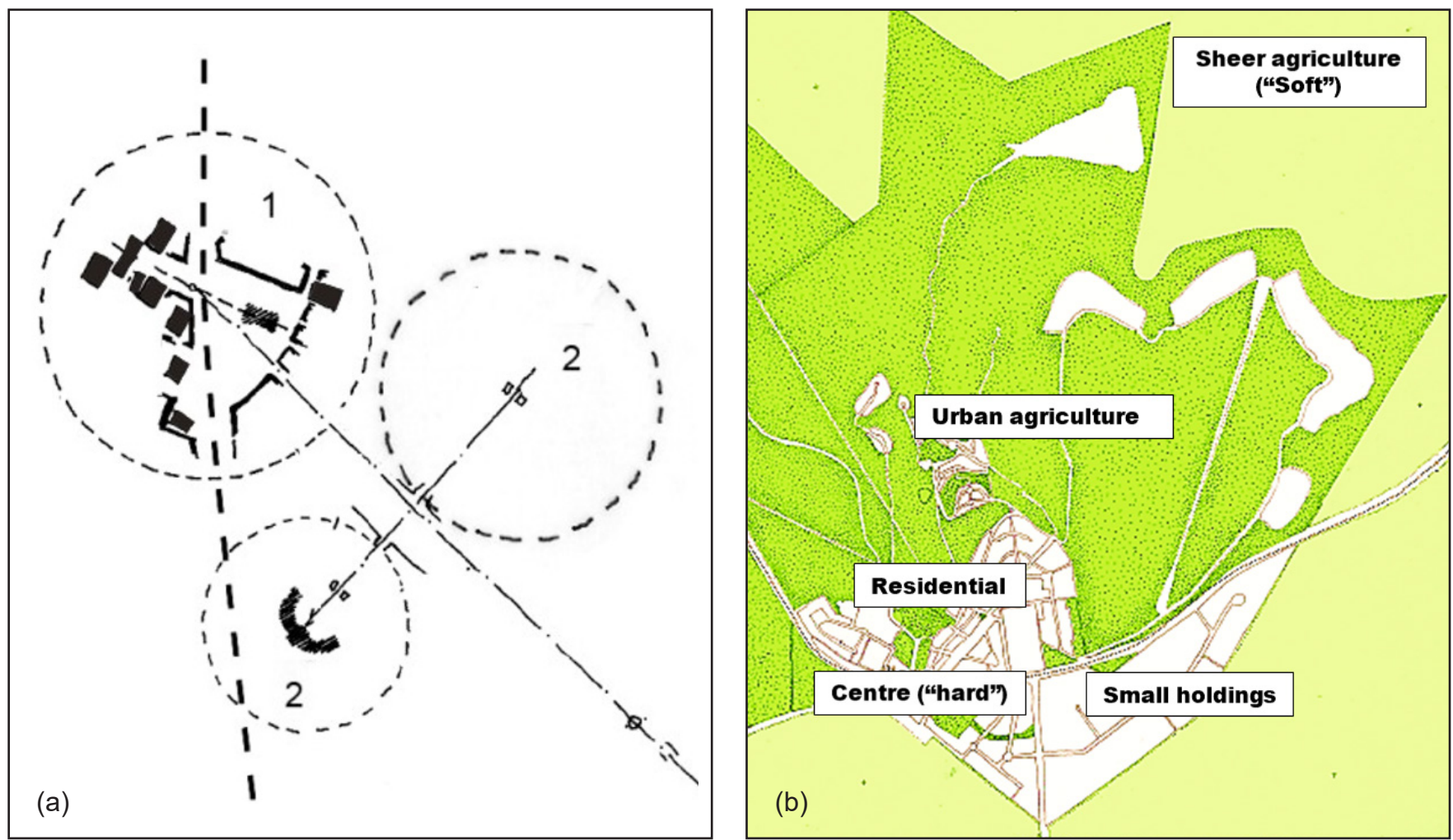

Figure 4: Dualistic planning: (a) "hard" areas; (b) "soft" areas

Source: $\quad$ GWA Studio, 2014: 7, 9

study. The ensuing discussion simply indicates an incipient exploration of the case study, signalling that continuing work is required and further articles should be anticipated.

Although the rural village of Verkykerskop dates back to the Anglo-Boer War (1899-1902), it was recently re-planned (20132016). It is located in the Free State province, South Africa; it comprises pristine views over the Drakensberg escarpment, and is set in a predominantly agricultural region. The multidisciplinary design team (Gary White \& Associates, Insite Landscape Architects, LMV Town and Regional Planners, MDA Environmental Specialists, Cobus Dreyer Archaeologist, KMA Traffic Engineers, appointed by Verkykerskop Township Development, and Verkykerskop Tourism) pinned its planning philosophy on enhancing the historic and cultural heritage of the rural area; protecting its rural and rich agriculture operative, and potentially unlocking its tourism and economic growth potential without impeding on its natural beauty and rural landscape features. This approach is sensed as an endeavour to intercept the village's "dying syndrome" (Keneley, 2004: 7) and the already prevalent symptoms thereof. Findings from the set design philosophy and disposition were comprehensively described in a Green Living Compendium (GWA Studio, 2014: 1-100), prepared for the future development of Verkykerskop. The compendium includes a detailed, comprehensive and diverse development plan (Trudeau, 2013: 23).

The first ordering principle of the "urban framework" is laid down as prominent places of historical, natural and agricultural significance (Figure 3[a]), counting the commercial and dense village commons from where development will disperse to a distant low-density residential zone, intertwining the different functions of equine, agricultural and weekend living activities (Rodenburg \& Nijkamp, 2004: 275). This design approach was also applied in the Windsor village by providing a well-defined village centre from where densities and activities gradually and ultimately disperse into outlying lowdensity, exclusively residential areas. Although Ching (2007) identifies the axis as the most elementary means of arranging forms and spaces in settlement design, its significance in Verkykerskop (Figure $3[b])$ is apparent as a powerful and regulating device, ordering prominent places. Figure 3(a) illustrates these places as (6) an existing gymkhana track (a social pivot in an area characterised by its horse breeding, horse racing, polo and gymkhana), linking the (1) village commons to the outlying predominantly low-density residential zones (7) and hamlets (4), with the visual and (2) picturesque forces of the Drakensberg escarpment further afield, the cultural village (5) and a farm dam (3). Since this axis is essentially a linear state of length and direction, it creates free pedestrian movement and views along its path, constituting a more environmentally friendly development attitude (Lehmann, 2010: 3).

In encouraging the optimal utilisation of scarce land (Vreeker, 2004: 14), a mere 50 ha is earmarked for the 
re-planned village, as the remaining farm (measuring 800 ha in extent) and its immediate hinterland proceed with diverse agricultural activities. The "green framework" (Figures 4 and 5) is reminiscent of a dualistic planning approach (Vereijken, 2002: 177), identifying "main road function" areas surrounding the village commons, a main road traversing the village (Figure 4[a]) and "openness, quietness and silence" areas on the village's peripheral environs, reserved for sheer agricultural activity (Figure 4[b]). Sustainable agricultural and environmental management (De Groot, 2005: 175) are integrated into the larger fabric of the village and its surrounding rural landscape in the "production framework" (Figure 5[a]). It warrants a combination of green open space (Lehman, 2010: 422), productive open space, productive streets, urban and rural productive space; all in generating a healthier, more liveable rural centre (Kraus, 2006: 27).

Urban agriculture is permissible on a combination of residential erven varying in size, allowing for production on larger erven, processing and marketing on smaller erven and thereby simultaneously applying different functions to the same parcel of land (Brandt \& Vejre, 2004: 1). In this instance, urban agriculture, herb gardening, organically grown produce and bio-intensive practices, among others, are anticipated (Figures 5[b] and 7[a]).

The significance of green infrastructure is dependent on "multifunctionality and its ability to offer sustainable solutions to several problems" (European Commission, 2012: 25). Focusing on specific solutions, smaller steps are ventured upon in preparing a matrix (Figure 6) displaying a mere selection of the projected ecosystem services for the various urban zones of the re-planned village. The projected ecosystem services, in combination with detailed green services allotted for every building typology (Figure 7[b]), introduce green resources and ecological system function incorporation as part of the infrastructural fabric of the village (Harrison et al., 2014: 67).

As elucidated, detailed housing typologies (Figure 7[a]) are identified for the village, further illustrating Lehman's (2010: 422) submissions of a "symbiosis between building and nature", including landscape (see Figure $7[\mathrm{~b}]$ ) as an innate component of planning by integrating "new forms of green" in buildings; all despite the anticipated increased density of the re-planned village. It is essential to distinguish between the two purposes of the proposed housing
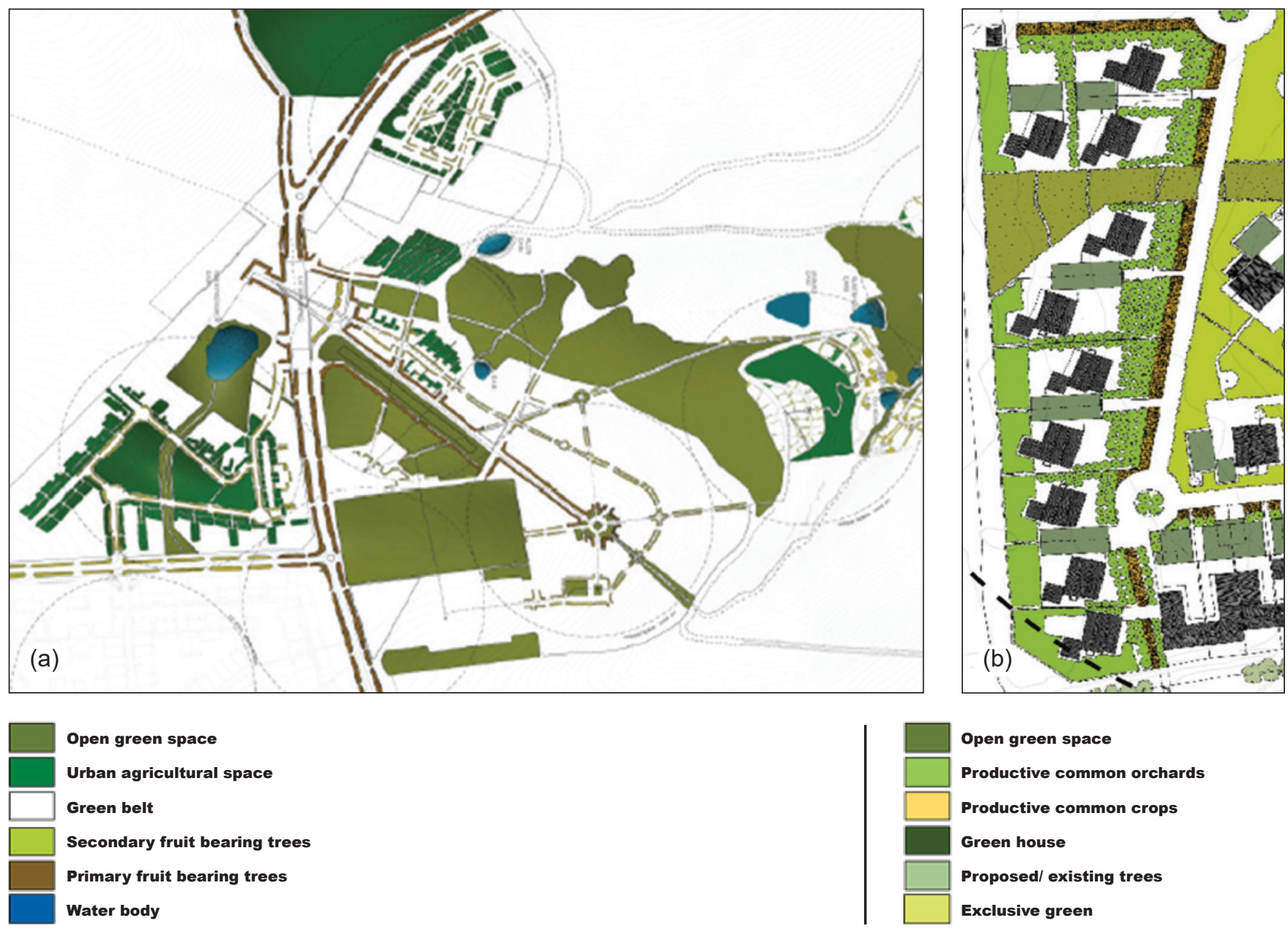

Figure 5: (a) Production framework; (b) Production and processing in the residential component

Source: $\quad$ GWA Studio, 2014: 21 
typologies. First, it aims to reflect and maintain the region's vernacular architecture (Versaci, 2008: 10) and, secondly, it seeks to demonstrate that with, inter alia, the use of building materials, the placement of buildings, water harvesting, energy generation and on-site waste disposal, housing is provided, in attaining some of the principles of GU.

The housing typologies all illustrate the collection of renewable energy (Figure 6[b]), as advised by Brandt et al. (2004: 22). The question arises whether the application of the NU planning approach, apart from its connectivity and walkability benefits, will undeniably decrease traffic. Crane (1996: 15-17) is hesitant and argues that the combination of its design features could either increase or decrease traffic; this may not necessarily be a "good thing".

By contrast, Hikichi (2003: 2, 26) identifies the benefits of walkable communities as enhancing a pleasant environment conducive to cycling and walking, thereby decreasing "environmental costs". Notwithstanding these contradicting insights, both scholars agree that the approach is a viable choice that must be continuously explored

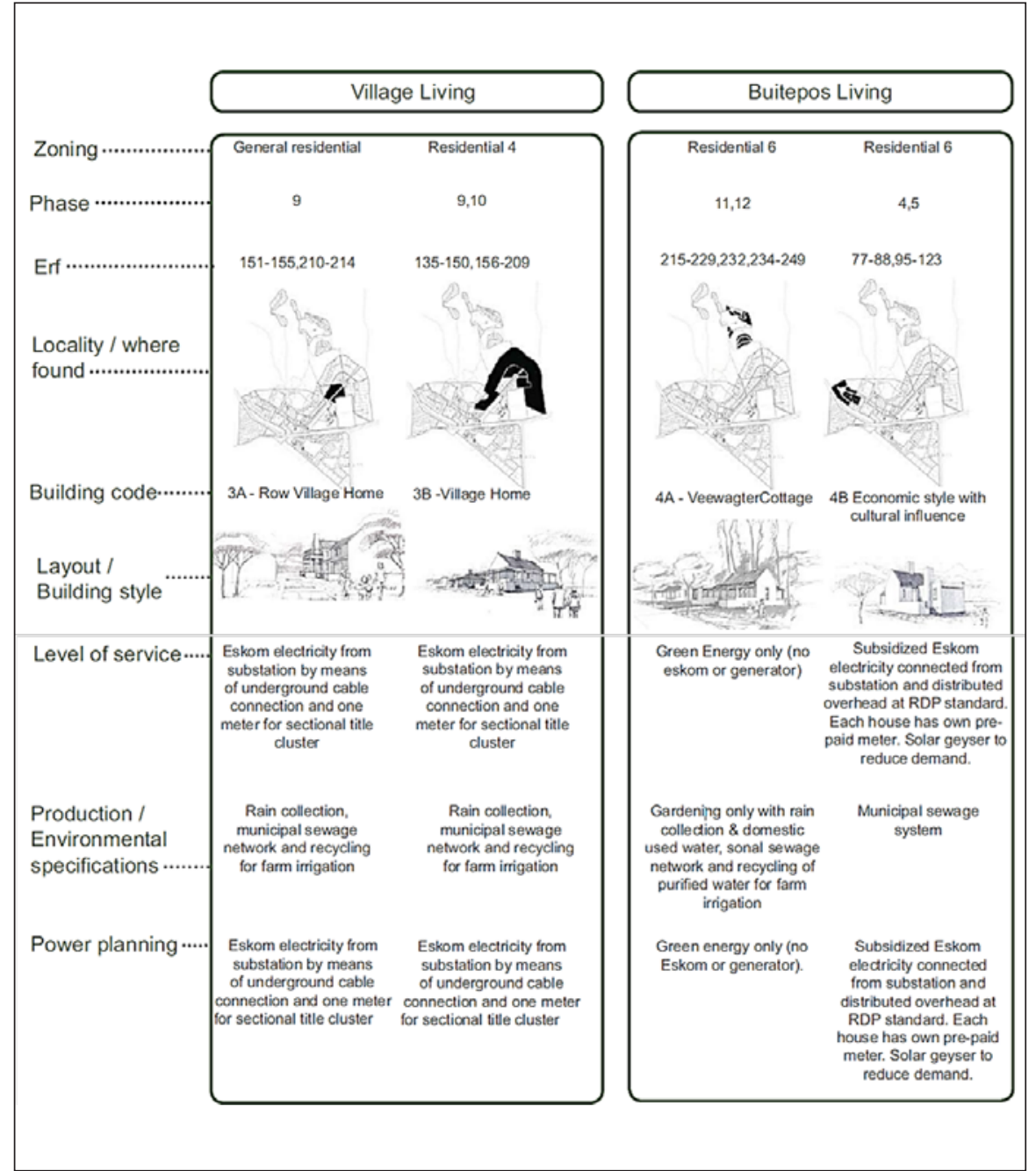

Figure 6: Matrix: Abstract of projected ecosystem services Source: $\quad$ GWA Studio, 2014: 29, 30

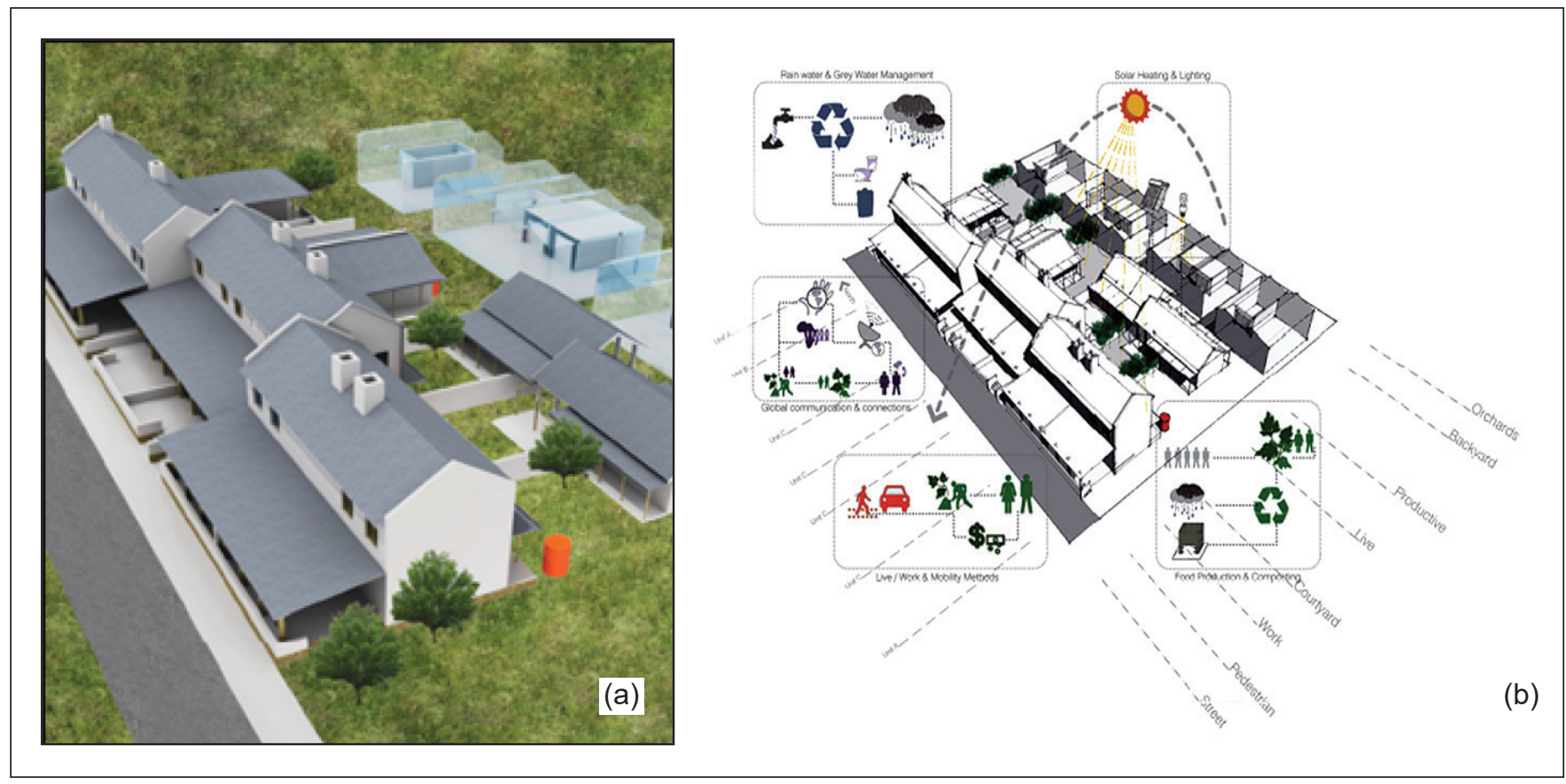

Figure 7: Housing typologies illustrating a symbiosis between building and nature

Source: $\quad$ GWA Studio, 2014: 51, 52 


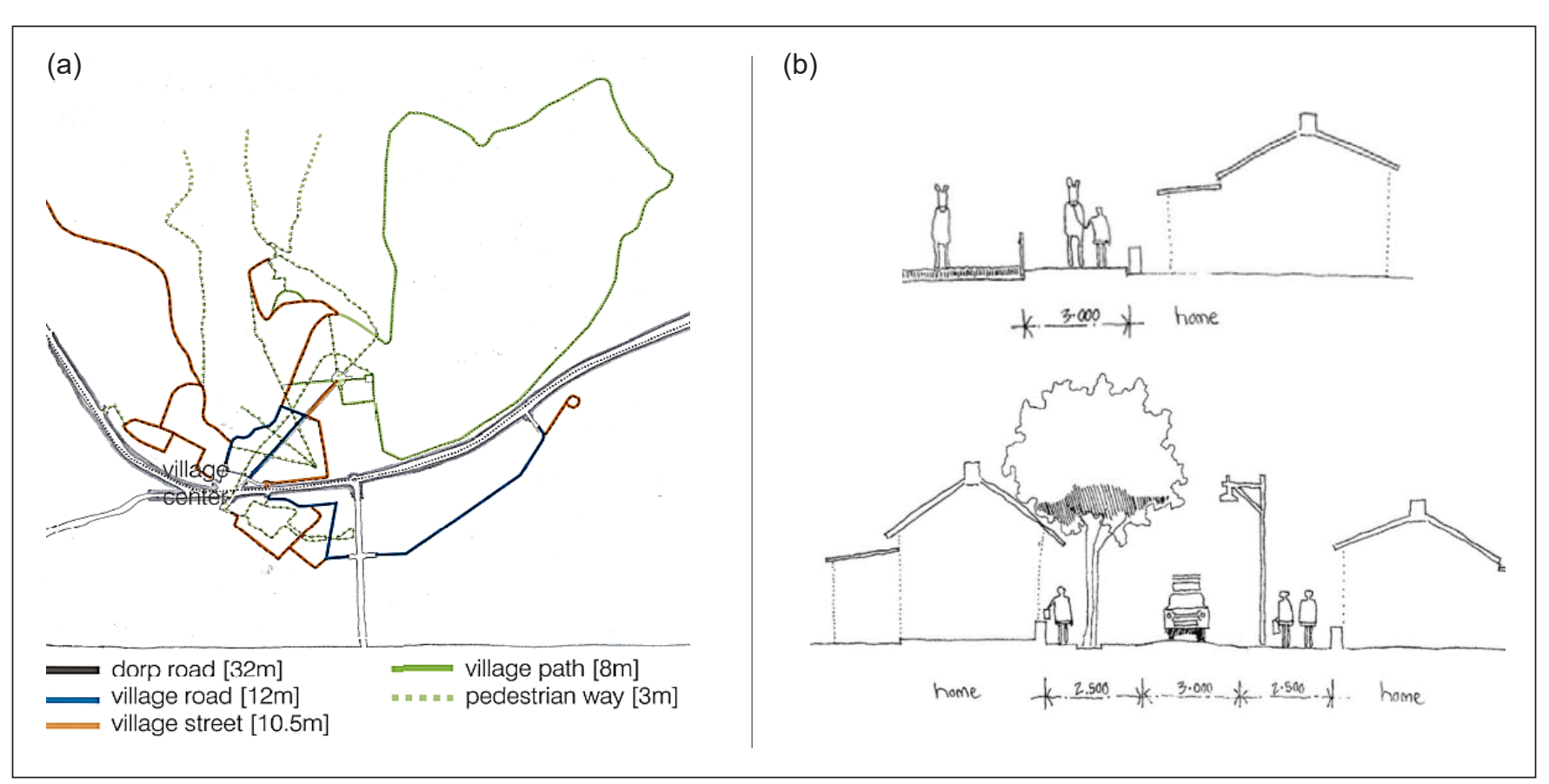

Figure 8: (a) Connectivity framework; (b) Selected examples of detailed street reserve designs

Source: $\quad$ GWA Studio, 2014: 10, 17

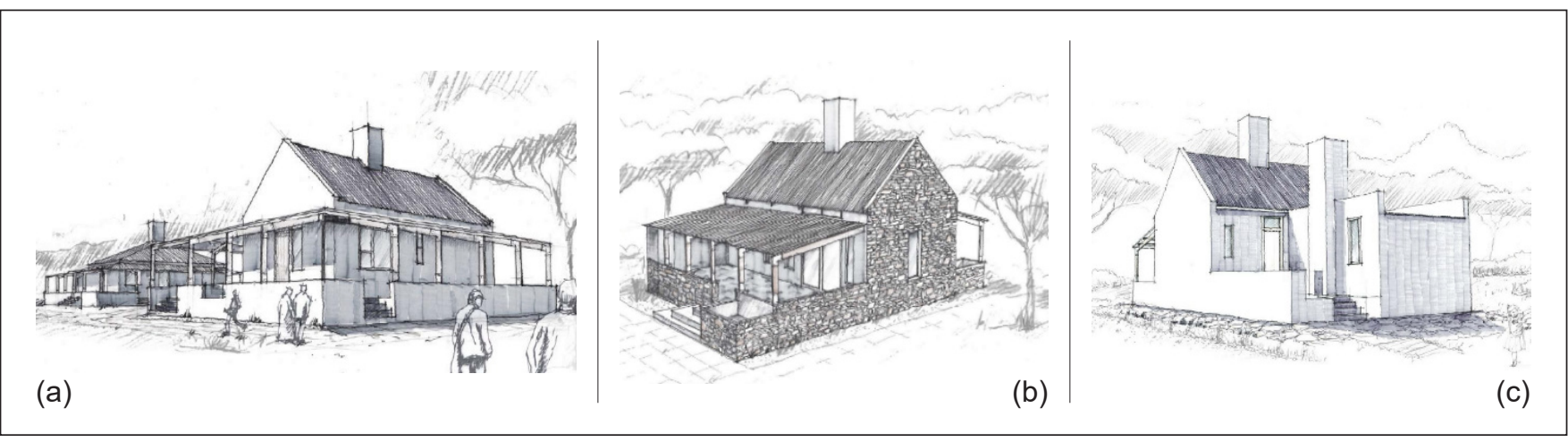

Figure 9: Selected housing typologies reflecting the regional vernacular architecture:

(a) village home; (b) economic style with cultural influences; (c) hunter's cottage

Source: $\quad$ GWA Studio, 2014: 30

in order to attain quality of life

(Hikichi, 2003: 26) and a clean environment (Vereijken, 2002: 174).

The application of NU planning principles in Verkykerskop advocates the linkages between landmarks and prominent land uses in a "connectivity framework" (Figure 8[a]) and detailed design of street reserves (Figure 8[b]). The connectivity framework prompts maximum choices and clear connections to existing places, routes and proposed routes (see Figure 3).

The resultant residential element (Pallarès-Blanch et al., 2014: 2;
Bielsa et al., 2005: 85-102) is measurably not monofunctional and commodity and non-commodity production and processing are, inter alia, permitted. In valuing Cilliers, Du Toit, Cilliers et al.'s (2014: 260) opinion that the South African urban landscape is rich in biodiversity and characterised by cultural diversity, but contains sharp socioeconomic differences, the "housing framework" presents a diversity in housing typologies, compliant with various, all-encompassing socio-economic groups, also fittingly infused with the region's vernacular architecture (Versaci, 2008: 10).
In providing characteristic precincts in Verkykerskop, the "Umgidi Village" (illustrated in Figure 10), offers housing opportunities incorporating the indigenous population's cultural heritage.

The re-planning of Verkykerskop contemplates a dualistic design (Vereijken, 2002: 177) in foreseeing a diverse "land use framework" (Figure 11), permitting higher densities, mixed land use, production and commercial related "hard" activities, gradually transecting to remote low-density areas comprising sheer residential "soft" activities, located in areas of wide expanses of agriculture, complemented by 


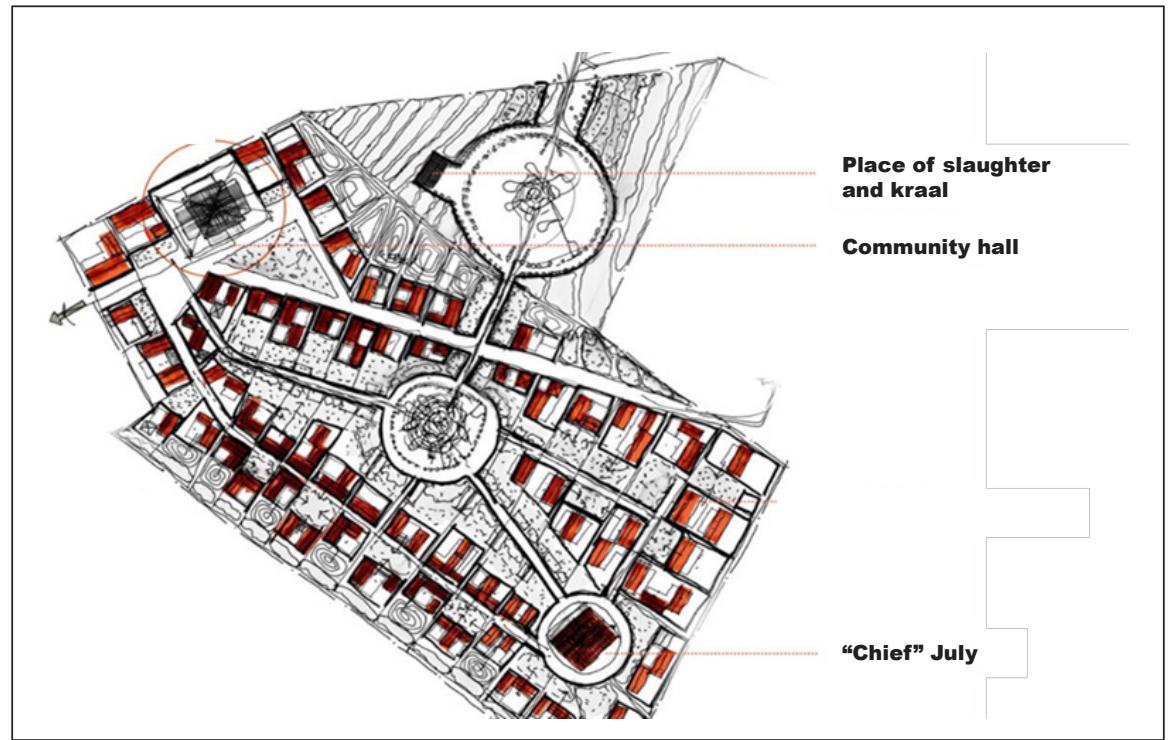

Figure 10: Umgidi Cultural Village

Source: $\quad$ GWA Studio, 2014: 24

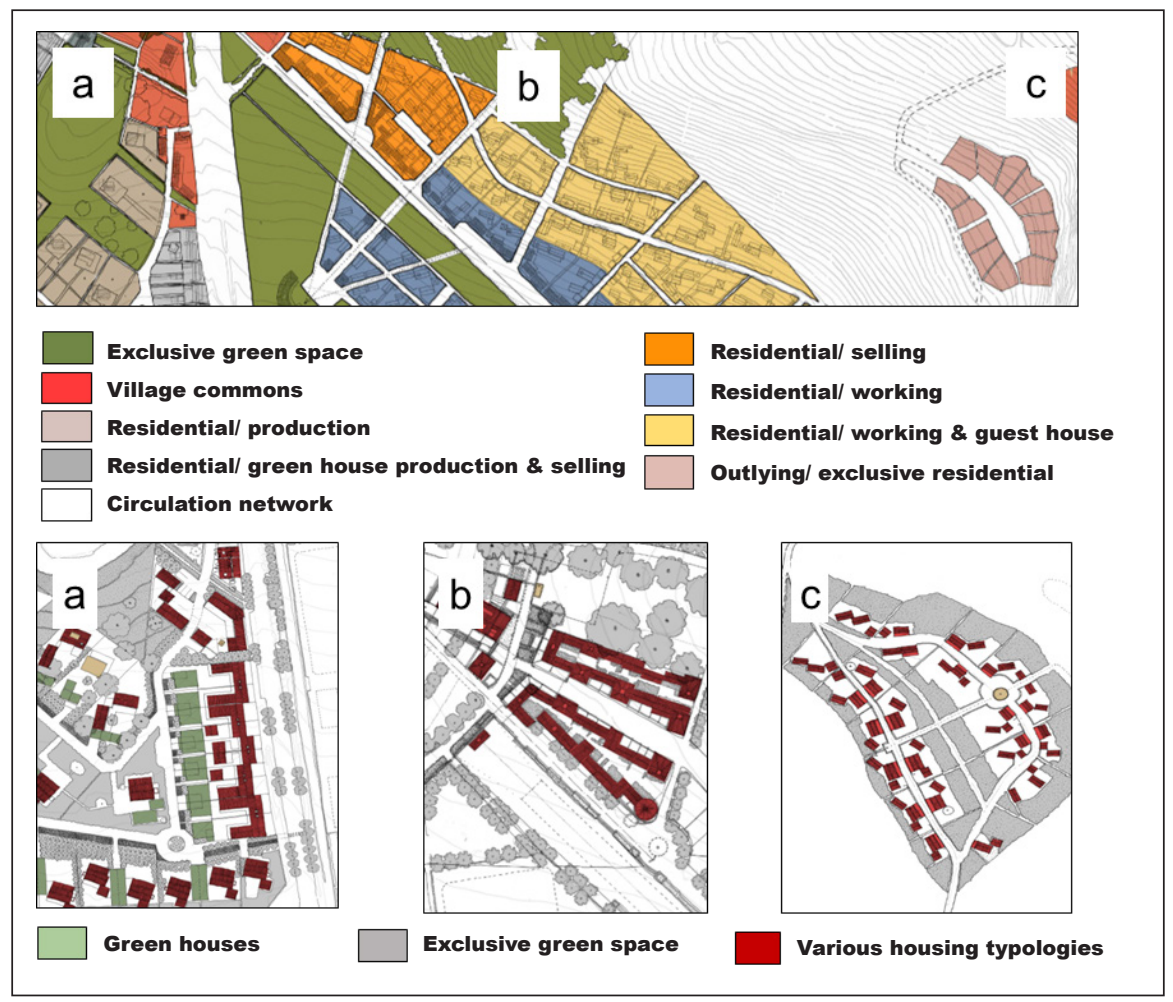

Figure 11: Density transect from (a) higher density residential village living/commercial/production; (b) mediumdensity living-commercial/ living-work; (c) lower density residential outspan living/expanses of agriculture

Source: $\quad$ GWA Studio, 2014: 22

other non-productive activities and functions (Elgåker, 2012: 592), areas for wildlife, habitat management, and passive recreation. In denoted areas, guest houses are intrinsically permitted, enhancing the region's tourism basis. Synergy-generating options are similarly reached by assigning permissible live-work and live-commercial residential options in medium-density areas; all introducing non-conventional land-use management policies (Dijst et al., 2010: 5). This specific arrangement emulates the Windsor model, where density is intensified around the village common and incrementally decreases in function and activity to the outlying low-density residential zone. This phenomenon is, to some extent, coherent with Burton's (2002: 226) identified key aspects of the compact city, i.e. high density, mixed use, and intensity. In addition, Matsumoto (2011: 17) emphasises the feasible employment of these key aspects on a smaller scale than the entire city and corroborates its significance in neighbourhood planning. In response to the "compact city" discourse, Verkykerskop illustrates a "density transect" from higher to medium to lower density zones (see Figure 11).

A holistic framework (Lehmann, 2010: 4) and revised policies (Dijst, 2010: 5) are essential in attaining the desired multifunctional rural landscape at Verkykerskop, in view of the complexity of the reciprocal use of various planning approaches and existing policies not tactic permitting a multifunctional approach towards settlement planning.

In closing: The preparation of unique Conditions of Establishment and of Title, especially in areas where green infrastructure is anticipated, substituting conventional services, is apparent. Obsolete development control measures do not necessarily comprise accommodating attributes towards multifunctional planning and dictate the compilation of an innovative Land Use Scheme.

Preparation of the above policies is evidently preceded by the "2050 vision" (Figure 12[a]) and an exceedingly exhaustive master plan (Figure 12[b]) drawn up for the village. Assigning fixed typologies to specific premises enables a series of inventive building control measures, especially building lines and the defining of novel land uses, i.e. urban agriculture, stables, courtyards, and vertical zoning (Figure 13[a] \& [b]). It is apparent that these specific and consequential planning policies are uncompromising in warranting the feasibility of the re-planned rural landscape (Kraus, 2006: 28). 

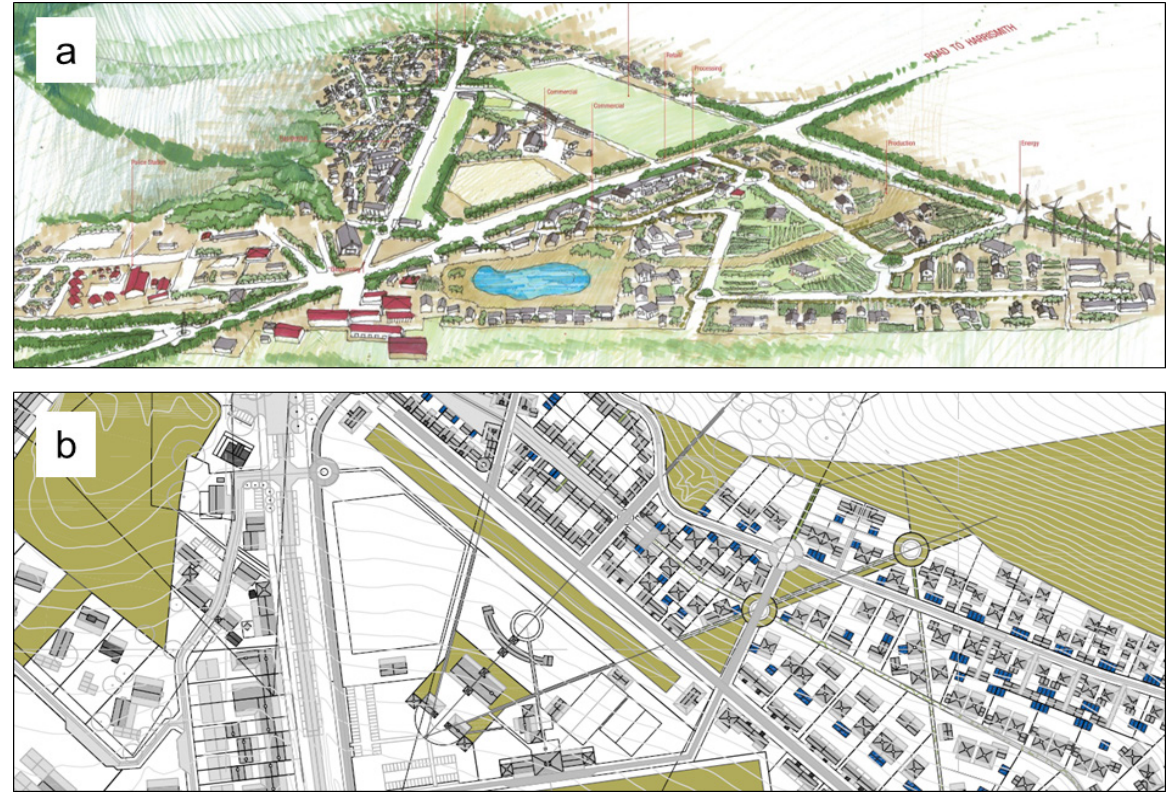

Figure 12: (a) "2050 vision"; (b) exhaustive master plan

Source: $\quad$ GWA Studio, 2014: 11
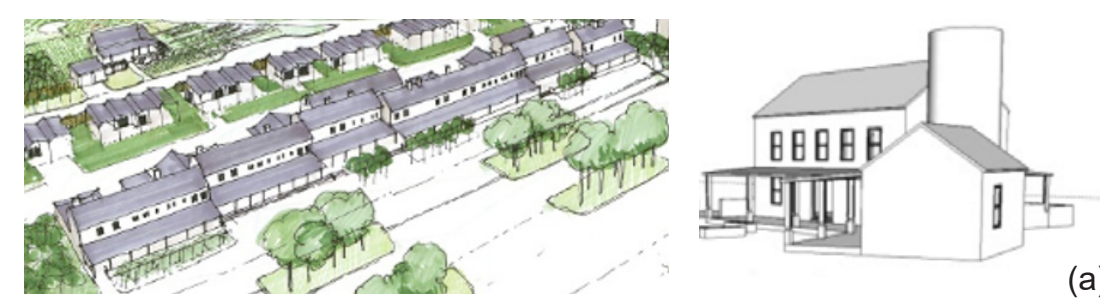

(a)
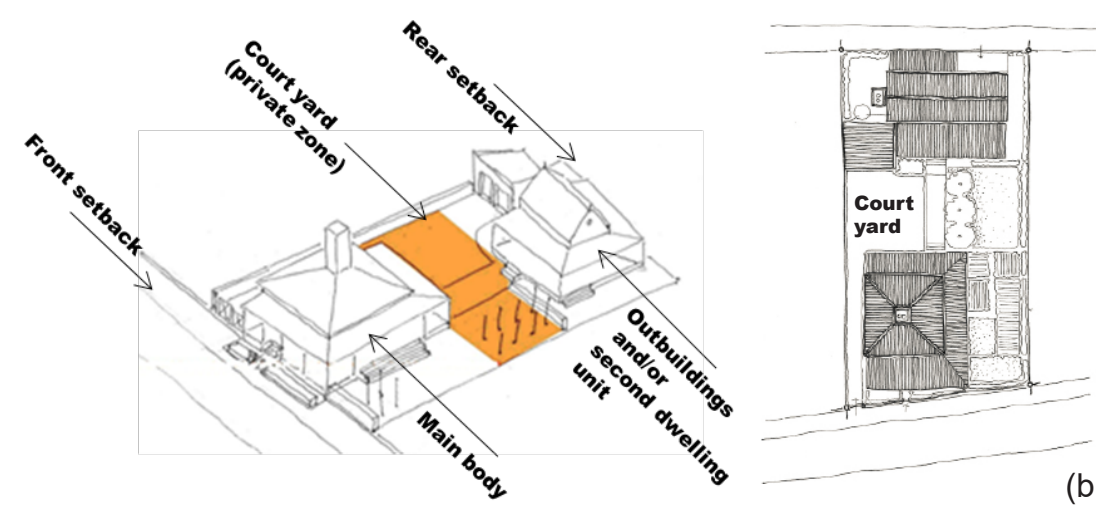

(b)

Figure 13: Illustrations applied in defining

(a) vertical zoning; (b) the "court yard"

Source: $\quad$ GWA Studio, 2014: 91

\section{CONCLUDING \\ THOUGHTS AND FUTURE DIRECTIONS FOR MULTIFUNCTIONALITY}

\subsection{Dealing with policy}

Resolute scholars in various disciplines deliberate

multifunctionality and its variations, especially those scholars in the regarded as an expedient solution for the planning of rural environments. It appears, however, that the practical application of multifunctionality is less familiar among its proponents. Practitioners and authorities will need to rethink multifunctionality on several levels. This means that accustomed planning approaches and development policies are no longer suitable. This article illustrates and argues that the reasonable hybrid and infused planning approaches are not necessarily included in prevalent policies and guidelines in a changing South Africa, for example, the Subdivision of Agricultural Land Act (No. 70 of 1970); Municipal Spatial Development Frameworks (SDFs); the Department of Rural Development and Land Reform's Guidelines for the preparation of SDFs (2014); Spatial Planning and Land Use Management Act (No. 16 of 2013), (considering the contents of SDFs and preparation of Land Use Schemes), and existing Municipal Land Use Schemes, unremittingly yearning for restructuring.

\subsection{Dealing with attainability}

There is no denying that the rural landscape is dramatically changing. Irrespective of its predominantly agricultural alignment and limited available examples of nonproductive tactics (for example, diversification of agricultural practices, non-agricultural land use, small retailers, protection, leisure, and living), the South African cadre seems silent, plagued by monofunctional advances and gazed with austerity by authorities. Small steps taken in re-planning Verkykerskop illustrate the feasibility of the devices of multifunctionality. The emerging analysis used in this article is indicative of potential "big" impacts, especially by pursuing interfaces between the applied planning approaches of NU, GU NR and multifunctionality. This article further illustrates multifunctionality's attainability in the rural landscape, causing the acceptance of the basic premise that multifunctionality will likely always be valid and even more so in future. 
It appears that multifunctionality, driven by its numerous benefits for the revitalisation of rural areas, is readily attainable amidst various planning approaches. The planning of multifunctional landscapes is an essential constituent of future rural life and ought to be a traversing theme.

\subsection{Dealing with planning approaches}

In emphasising the assets and liabilities of the three planning approaches of NU, NR and $\mathrm{GU}$, the article highlighted the unique planning highlights of each approach as potential "surprising steps towards something better". Admittedly, the application of a single planning approach may partially accomplish multifunctionality, although it is preferably agreed with Ahern's (2011: 4) assertion that multifunctionality aims to effectively intertwine or combine different functions in a restricted space. The sum of the reciprocal application of more than one planning approach may negate some of the limitations resulting from applying a single approach. A developing analysis of the planning features of the re-planned Verkykerskop village shows that several of the identified principles of multifunctionality are readily endorsed by the simultaneous application of NU, NR and GU. Finding interfaces among the three planning approaches increasingly informed multifunctionality.

\subsection{Dealing with interfacing}

Based on the limitations of this article, it is accepted that neither the principles of multifunctionality, nor its interface with the contemplated planning approaches are exhaustive. Assuming that the multiple indicators and "copious data" result from the applied methodological approach, Thoreau's (1990: 61) philosophical recommendation in 1854 to simplify and simplify seems enticing.

Paracchini, Pacini, Laurence et al. (2011: 79) advise to the contrary: not to simplify a complex world, especially when seeking to proceed with an "aggregation framework for multiple indicators". They caution that the vulnerability of simplification lies in distantly viewing reality. In seeking an optimum level between the planning approaches and multifunctionality, interfacing offers a valuable instrument to distil information into a comparative "aggregation framework", instead of attempting to simultaneously construe multiple attributes.

Further investigation of the planning approaches and multifunctionality may reveal more interfaces; more practical solutions might evolve, and refining the interfaces be realised.

Although there is no simple way out of a changed world, several small steps "towards something better" are deemed essential in seeking "bigger" impacts, of which the leitmotif of multifunctional planning is, perhaps, a keel that may well stabilise the rapidly changing rural landscape. Positive, yet small steps may well be taken in accomplishing the changes that are necessary to bring about a stronger sense of community and to develop a broader vision than that which is evident in known practices. In conclusion: it is agreed with Hall and Porterfield (2001: xxii) "that we must be proactive in effecting change", rather than being despondent in the midst of this chopping sea of a changed world.

\section{REFERENCES}

ADESINA, A.A., GURRIA, A., HELEN, C. (Eds). 2016. African economic outlook: Sustainable cities and structural transformation. Paris: OECD Publications. [online]. Available at: <www. africaneconomicoutlook. org/sites/default/files/contentpdf/eBook_AEO2016.pdf> [Accessed: 29 June 2017].

AHERN, J. 2011. From fail-safe to safe-to-fail: Sustainability and resilience in the new urban world. Landscape and Urban Planning, 100(4), pp. 241-343. https://doi.org/10.1016/j. landurbplan.2011.02.021

AHI (AFRIKAANSE

HANDELSINSTITUUT), DCOG (DEPARTMENT OF COOPERATIVE GOVERNANCE
AND TRADITIONAL AFFAIRS) \& GIZ (DEUTSCHE GESELSCHAFT FUR INTERNATIONALE ZUSAMMENARBEIT). 2016. Small towns development initiative. Pretoria: $\mathrm{AHI}$ and DCOG.

ARENDT, R. 1994. Rural by design: Maintaining small town character. Chicago, ILL: American Planning Association.

ARTMANN, M., BASTIAN, O. \& GRUNEWALD, K. 2017. Using the concept of green infrastructure and ecosystem services to specify Leitbilder for compact and green cities - The example of the landscape plan of Dresden (Germany). Sustainability, 9(198), pp. 1-26. https://doi. org/10.3390/su9020198

AUDIRAC, I., SHERMYEN, A.H. \& SMITH, M.T. 1990. Ideal urban form and good visions of the good life Florida's growth management dilemma. Journal of the American Planning Association, 56(4), pp. 470-482. https:// doi.org/10.1080/01944369008975450

BALMFORD, A., BRUNER, A., COOPER, P., CONSTANZA, R., FARBER, S., GREEN, R.E., JENKINS, M., JEFFERISS, P., JESSAMY, V., MADDEN, J., MUNRO, K., MYERS, N., NAEEM, S., PAAVOLA, J., RAYMENT, M., ROSENDO, S., ROUGHGARDEN, J., TRUMOER, K. \& TURNER, R.K. 2002. Economic reasons for conserving wild nature. Science, 297(5583), pp. 950-953. https://doi.org/10.1126/ science.1073947

BATTY, M., BESUSSI, E., MAAT, K \& HARTS, J.J. 2004. Representing multifunctional cities: Density and diversity in space and time. Built Environment, 30(4), pp. 324-337. https://doi.org/10.2148/ benv.30.4.324.57156

BEATLEY, T. \& NEWMAN, P. 2009.

Green urbanism down under. Washington, D.C.: Island Press.

BIELSA, I., PONS, X. \& BUNCE, B. 2005. Agricultural abandonment in the North Eastern Iberian peninsula: The use of basic landscape metrics to support planning. Journal of Environmental Planning and Management, 48(1), pp. 85-102. https://doi. org/10.1080/0964056042000308166

BOHL, C.C. 2000. New urbanism and the city: Potential applications and implications for distressed inner-city neighborhoods. Housing Policy Debate, 
11(4), pp. 761-801. https://doi.org/10.10 80/10511482.2000.9521387

BOHMAN, M., COOPER, J., MULLARKEY, D., NORMILE, M., SKULLY, D., VOGEL, S. \& YOUNG, E. 1999. The uses and abuses of multifunctionality. Economic Research Service. Washington, D.C.: United States Department of Agriculture.

BRANDT, J. \& VEJRE, H. 2004. Multifunctional landscapes - Motives, concepts and perceptions. In: Brandt, J. \& Vejre, H. (Eds). Multifunctional landscapes: Volume 1: theory, values and history. Southampton: WIT Press, pp. 3-32.

BURTON, E. 2002. Measuring urban compactness in UK towns and cities. Environment and Planning B: Planning and Design, 29(1), pp. 219-250. https:// doi.org/10.1068/b2713

CARTER, F. 1998. The education of little tree. Albuquerque, NM: University of New Mexico Press.

CASTELLS, M. 1992. The world has changed: Can planning change? Landscape and Urban Planning, 22(1), pp. 73-78. https://doi. org/10.1016/0169-2046(92)90009-O

CILLIERS, S.S., DU TOIT, M., CILLIERS, E.J., DREWES, J.E. \& RETIEF, F. 2014. Sustainable urban landscapes: South African perspectives on transdisciplinary possibilities. Landscape and Urban Planning, 125, pp. 260-270. https://doi.org/10.1016/j. landurbplan.2014.02.009

CHING, F.D.K. 2007. Architecture form, space and order. Hoboken, NJ: John Wiley \& Sons Inc.

\section{CHURCHMAN, A. 1999.}

Disentangling the concept of density. Journal for Planning Literature, 13(4), pp. 389-411. https://doi. org/10.1177/08854129922092478

COHEN, L., MANION, L. \& MORRISON, K. 2018. Research methods in education. New York, NY: Routledge.

CRANE, R. 1996. On form versus function: Will the "new urbanism" reduce traffic or increase it. Journal of Planning Education and Research, 15(2), pp. 1-26. https://doi. org/10.1177/0739456X9601500204

DANBOM, D.B. 1995. Born in the country: A history of rural America. Baltimore, MD: Johns Hopkins University Press.
DAVIDOFF, P. 1965. Advocacy and pluralism in planning. Journal of the American Institute for Planners, 31(4), pp. 331-338. https://doi. org/10.1080/01944366508978187

DAY, K. 2009. New urbanism and the challenges of designing for diversity. Journal of Planning Education and Research, 23(1), pp. 83-95. https://doi. org/10.1177/0739456X03255424

DE GROOT, R. 2005. Functionanalysis and the valuation as a tool to assess land use conflicts in planning for sustainable, multi-functional landscapes. Landscape and Urban Planning, 75(3), pp.175-186.

DIJST, M., ELBERSEN, B. \& WILLIS, K. 2010. The challenge of multifunctional land use in rural areas. Journal of Environmental Planning and Management, 48(1), pp. 3-6. https://doi. org/10.1080/0964056042000308120

DUANY, A. \& PLATER-ZYBERK, E. 1992. The second coming of the American small town. The Wilson Quarterly, 16(1), pp. 19-48.

DUANY, A., PATER-ZYBERK, E. \& SPECK, J. 2010. Suburban nation: The rise of sprawl and the decline of the American dream. New York, NY: North Point Press.

ELGÅKER, H.E. 2012. The new equine sector and its influence on multifunctional land use in periurban areas. GeoJournal, 77(5), pp. 591-613. https://doi.org/10.1007/ s10708-010-9398-y

ELLIS, C. 2002. The new urbanism: Critiques and rebuttals. Journal of Urban Design, 7(3), pp. 261-291. https://doi. org/10.1080/1357480022000039330

EUROPEAN COMMISSION. 2004. New perspectives for EU rural development, fact sheet. [Online]. Available at: <https://ec.europa.eu/ agriculture/publi/fact/rurdev2007/2007_ en.pdf> [Accessed: 31 March 2018].

EUROPEAN COMMISSION. 2012. The multifunctionality of green infrastructure. [Online]. Available at: <http://ec.europa.eu/ environment/nature/ecosystems/ docs/Green_Infrastructure.pdf> [Accessed: 4 April 2018].

FRAM, S.M. 2013. The constant comparative analysis method outside of grounded theory. The Qualitative Report, 18(1), pp.1-25.
FREILICH, R.H. \& POPOWITZ, N.M 2010. The umbrella of sustainability: Smart growth, new urbanism, renewable energy and green development in the 21 st century. The Urban Lawyer, 42(1), pp.1-39.

GUNDER, M. \& HILLER, J. 2009. Planning in ten words or less. Surrey, UK: Ashgate Publishing Company.

GWA STUDIO. 2014. Verkykerskop Green Living Compendium (unpublished), pp. 1-100.

HALL, K.B. \& PORTERFIELD, G.A. 2001. Community by design. New York, NY: McGraw Hill.

HANSEN, R. \& PAULEIT, S. 2014. From multifunctionality to multiple ecosystem services? A conceptual framework for multifunctionality in green infrastructure planning for urban areas. Ambio, 43(4), pp. 516-529. https://doi. org/10.1007/s13280-014-0510-2

HARRISON, P., BOBBINS, K., CULWICK, C., HUMBY, T., LA MANTIA, C., TODES, A. \& WEAKLEY, D. 2014. Urban resilience thinking for municipalities. University of the Witwatersrand, Gauteng City-Region Observatory.

HEDMAN, R \& JASZEWSKI, A. 1984. Fundamentals of urban design. Chicago, ILL: American Planning Association.

HIKICHI, L. 2003. New urbanism and transportation. University of WisconsinMilwaukee, pp. 1-28.

HOLMES, J. 2006. Impulses towards a multifunctional transition in rural Australia: Gaps in the research agenda. Journal of Regional Studies, 22(2), pp. 142-160.

HOWARD, E. 1902. Garden cities of tomorrow. London: Swan Sonnenschein \& Co.

IURD (INSTITUTE OF URBAN AND

REGIONAL DEVELOPMENT) \& SAGE (SUSTAINABLE AGRICULTURE EDUCATION). 2006. Summary of workshop - Developing a framework for new realism, held at the University of California, Berkeley, 7 April. [online]. Available at: <http:// newruralism.pbworks.com/f/New\%20 Ruralism\%20Workshop20060407.pdf> [Accessed: 30 June 2017].

JACOBS, J. 1961. The death and life of great American cities. New York, NY: Random House. 
JEPSON, E.J. \& EDWARDS, M.M. 2010. How possible is sustainable urban development? An analysis of planners' perceptions about new urbanism, smart growth and the ecological. Planning Practice \& Research, 25(4), pp. 417-437. https:// doi.org/10.1080/02697459.2010.5110 16

JOHNSON, J.D. \& RASKER, R. 1995. The role of economy and quality of life values in rural business location. Journal of Rural Studies, 11(4), pp. 405-416. https://doi. org/10.1016/0743-0167(95)00029-1

KATZ, P. 1994. The new urbanism: Toward an architecture of community. New York, NY: McGraw-Hill.

KENELEY, M. 2004. The dying town syndrome: A survey of urban development in the western district of Victoria 1830-1930. The Electronic Journal of Australian and New Zealand History, pp. 1-14. [online]. Available at: <http://dro.deakin.edu. au/eserv/DU:30002410/keneleydyingtownsyndrome-2004.pdf> [Accessed: 30 June 2017].

KOPEVA, D., PENEVA, M. \& MADJAROVA, S. 2010. Multifunctional land use: Is it a key factor for rural development? Paper prepared for the 118th seminar of the European Association of Agriculture Economists, 25-27 August, Ljubljana, Slovenia.

KRAUS, S. 2006. A call for new ruralism. [online]. Available at: $<$ https://frameworks.ced.berkeley. edu/2006/a-call-for-new-ruralism/> [Accessed: 30 June 2017].

KVORNING, J. 2016. Ruralism and periphery: The concept of ruralism and discourses on ruralism in Denmark. In: Carlow, V.M. (Ed.). Ruralism - The future of villages and small towns in an urbanizing world. Berlin: Jovis, pp. 26-39.

LAFORTEZZA, R., DAVIES, C., SANESI, G. \& KONIJNENDIJK, C.C. 2013. Green infrastructure as a tool to support spatial planning in European regions. iForest, 6, pp. 102-108.

LEHMANN, S. 2010. Green urbanism: Formulating a series of holistic principles. Surveys and Perspectives Integrating Environment and Society, 3(2), pp.1-10.

LOUW, M.P. 2012. The new urbanism and new ruralism frameworks as potential tools for sustainable rural development in South Africa. M.Phil. thesis. Stellenbosch: Stellenbosch University.

MACHOR, J.L. 1987. Pastoral cities: Urban ideals and the symbolic landscape of America. Madison, WI: University of Wisconsin Press.

MARSDEN, T., MURDOCH, J., LOWE, P., MUNTON, R. \& FLYNN, A. 1993. Constructing the countryside. London: UCL Press.

MARSDEN, T. \& SONNINO, R. 2008. Rural development and the regional state: Denying multifunctional agriculture in the UK. Journal of Rural Studies, 24(4), pp. 422-431. https://doi. org/10.1016/j.jrurstud.2008.04.001

MATSUMOTO, T. 2011. Compact city policies: A comparative assessment - Final Report. Washington, D.C.: Organisation for Economic Cooperation and Development (OECD).

MAYO, J.M. \& ELLIS, C. 2009. Capitalist dynamics and new urbanist principles: Junctures and disjunctures in project development. Journal of Urbanism: International Research on Placemaking and Urban Sustainability, 2(3), pp. 237-257. https://doi. org/10.1080/17549170903466061

McHARG, I.L. 1971. Design with nature. New York, NY: Doubleday.

McHARG, I.L. 1981. Human ecological planning at Pennsylvania. Landscape Planning, 8(2), pp. 109-120. https://doi. org/10.1016/0304-3924(81)90029-0

MOFFAT, D. 2006. New ruralism: Agriculture at the metropolitan edge [dispatch]. Places, 18(2), pp. 71-75.

MOUDON, A.V. 2000. Proof of goodness: A substantive basis for new urbanism? Places, 13(2), pp. 38-43.

MUSCHAMP, H. 1996. Can new urbanism find room for the old? [online]. Available at: <https://www.nytimes. com/1996/06/02/arts/architecture-viewcan-new-urbanism-find-room-for-theold.html> [Accessed: 4 April 2018].

NELSON, G.D. 2009. Towards the new ruralism. Cambridge, MA: Harvard University Press.

NEWBY, P. 2010. Research methods for education. Harlow, UK: Pearson Education Ltd.

NEWMAN, G. \& SAGINOR, J. 2016. Priorities for advancing the concept of new ruralism. Sustainability, 8(269), pp. 1-15. https://doi.org/10.3390/ su8030269

NIJKAMP, P. 1980. Herfsttij der vooruitgang. Groningen, The Netherlands: Uitgeverij De Vuurbraak.

OECD (ORGANISATION FOR ECONOMIC CO-OPERATION AND DEVELOPMENT). 2001. Multifunctionality: Towards an analytical framework. Paris: OECD Publications.

PALLARÈS-BLANCH, M., PRADOS, M.J. \& TULLA, A.F. 2014. Naturbanization and urban-rural dynamics in Spain: Case study of new rural landscapes in Andalusia and Catalonia. European Countryside, 6(2), pp. 118-160. https://doi.org/10.2478/ euco-2014-0008

PALMER, H. \& SIMON, D. 2016.

Conclusions, implications and practical guidelines. In: Simon, D. (Ed.). Rethinking sustainable cities: Accessible, green and fair. Bristol: Policy Press, pp. 145-166.

PARACCHINI, M.L., PACINI, C., LAURENCE, M., JONES, M. \& PE'REZ-SOBA, M. 2011. An aggregation framework to link indicators associated with multifunctional land use to the stakeholder evaluation of policy options. Ecological Indicators, 11, pp. 71-80. https://doi.org/10.1016/j. ecolind.2009.04.006

PLATER-ZYBERK, D. 2014. The lexicon of new urbanism. Miami, FL: DPZ. [online]. Available at <http://www. dpz.com/uploads/Books/Lexicon-2014. pdf.> [Accessed: 26 April 2018].

PRIEMUS, H. \& HALL, P. 2004. Multifunctional urban planning of megacity-regions. Built Environment, 30(4), pp. 338-349. https://doi.org/10.2148/ benv.30.4.338.57154

QUIN, D. 1999. Beyond civilization. New York, NY: Three Rivers Press.

RETIEF, F., BOND, A., POPE. J., MORRISON-SAUNDERS, A. \& KING, N. 2016. Global megatrends and their implications for environmental assessment practice. Environmental Impact Assessment Review, 61, pp. 52-60. https://doi.org/10.1016/j. eiar.2016.07.002

RODENBURG, C.A. \& NIJKAMP, P. 2004. Multifunctional land use in the city: A typological overview. Built Environment, 30(4), pp. 274-288. https://doi.org/10.2148/ benv.30.4.274.57152 
ROSS, E. \& BIGON, L. 2018. The urban grid and entangled planning cultures in Senegal. Planning Perspectives, 33(2), pp. 1-26. https:// doi.org/10.1080/02665433.2018.1453 860

RSA (REPUBLIC OF SOUTH AFRICA). 2013. Spatial Planning and Land Use Management Act, Act 16 of 2013.

Pretoria: Government Printer.

RSA (REPUBLIC OF SOUTH AFRICA). 2015. Department of Rural

Development and Land Reform. Strategic plan 2015-2020. Pretoria: Government Printer.

SCHAMA, S. 1995. Landscape and memory. New York: Alfred A. Knopf.

SHARIFI, A. 2016. From garden city to eco-urbanism: The quest for sustainable neighbourhood development. Sustainable Cities and Society, 20, pp. 1-16. https://doi. org/10.1016/j.scs.2015.09.002

SURI, H. 2011. Purposeful sampling in qualitative research synthesis. Qualitative Research Journal, 11(2), pp. 63-75. https://doi.org/10.3316/ QRJ1102063

STRATTON, E.M. 2009. New ruralism. [online]. Available at: $<$ http://digitalcommons.law.uga.edu/ landuse/18> [Accessed: 4 April 2018].

TALEN, E. 2000. New urbanism and the culture of criticism. Urban Geography, 21(4), pp. 318-341. https:// doi.org/10.2747/0272-3638.21.4.318

TALEN, E. 2002. The social goals of new urbanism. Housing Policy Debate, 13(1), pp. 165-188. https://doi.org/10.10 80/10511482.2002.9521438

TALEN, E. 2013. Charter for the new urbanism. New York, NY: McGraw-Hill Education.

THOREAU, H.D. 1990. Walden. Philadelphia, PA: Courage Books.

TÎRLĂ, M.L., MANEA, G., VIJULIE, I., MATEI, E. \& COCOS, O. 2014. Green cities - Urban planning models of the future. In: Efe, R., Sam, N., Sam, R., Spiriajevas, E. \& Galay, E. (Eds). Cities in the globalizing world and Turkey: A theoretical and empirical perspective. Sofia, Bulgaria: St Kliment Ohridski University Press, pp. 462-479.

TRUDEAU, D. 2013. A typology of new urbanism in neighborhoods. Journal of Urbanism: International Research on Placemaking and Urban Sustainability,
6(2), pp. 113-138. https://doi.org/10.108 o/17549175.2013.771695

VEREIJKEN, P.H. 2002. Transition to multifunctional land use and agriculture. Netherlands Journal of Agricultural Science, 50(2), pp. 171-179.

VERSACI, R. 2008. New ruralism Developers are looking to our agrarian past to create communities. Old House Journal's New House, Spring 2008, pp. 10-11. [online]. Available at: <http:// www.russellversaci.com/New_Ruralism. pdf> [Accessed: 30 June 2017] .

VREEKER, R. 2004. Urban multifunctional land use and externalities. Paper presented at the European Regional Science Association Conference, 25-29 August, Porto, Portugal. Available at: <http://www-sre.wu.ac.at/ersa/ ersaconfs/ersa04/PDF/346.pdf>

WESSELS, K.J., PRINCE, S.D., FROST, P.E. \& VAN ZYL, D. 2004. Assessing the effects of humaninduced land degradation in the former homelands of northern South Africa with a $1 \mathrm{~km}$ AVHRR NDVI time-series. Remote Sensing of Environment, 91(1), pp. 47-67. https://doi.org/10.1016/j. rse.2004.02.005

WIGGERING, H., DALCHOW, C., GLEMNITZ, M., HELMING, K., MÜLLER, K., SCHULTZ, A., STACHOW, U. \& ZANDER, P. 2006. Indicators for multifunctional land use - Linking socio-economic requirements with landscape potentials. Ecological Indicators, 6(1), pp. 238-249.

WILSON, G. 2010. Multifunctional 'quality' and rural community resilience. Transactions of the Institute of British Geographers, 35(3), pp. 364-381.

YIN, R.K. 2003. Case study research: Design and methods. 3rd edition. London: Sage Publications. 